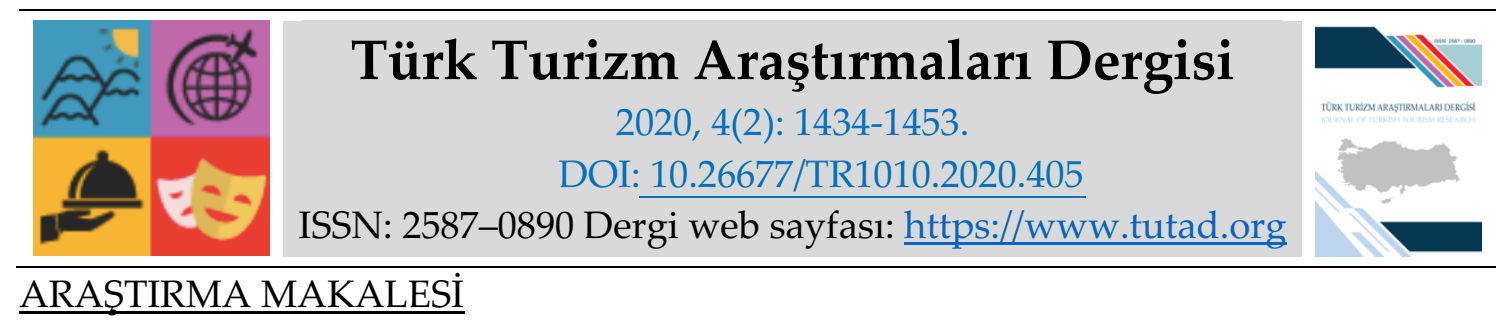

\title{
Hazırlanmakta Olan Turizm Konulu Lisansüstü Tezlerin Veri Görselleştirme Tekniği ile Bibliyometrik Analizi: 2006-2020 Yılları Örneği
}

Arş. Gör. Mehmet BOYRAZ, Afyon Kocatepe Üniversitesi, Turizm Fakültesi, Afyonkarahisar, eposta: mboyraz@aku.edu.tr

ORCID: https://orcid.org/0000-0001-6755-1999

Arş. Gör. Ali KABAKULAK, Afyon Kocatepe Üniversitesi, Turizm Fakültesi, Afyonkarahisar, eposta: alikabakulak@aku.edu.tr

ORCID: https://orcid.org/0000-0001-9256-8557

Arş. Gör. Asilhan Semih MUTLU, Afyon Kocatepe Üniversitesi, Turizm Fakültesi, Afyonkarahisar, e-posta: smutluc@aku.edu.tr

ORCID: https://orcid.org/0000-0002-5235-7090

\section{Öz}

Bu araştırmanın amacı, Yüksek Öğretim Kurulu (YÖK) Başkanlığı Tez Merkezi'nde yer alan turizm konulu hazırlanmakta olan lisansüstü tezlerin veri görselleştirme tekniği ile bibliyometrik olarak incelenmesidir. Tezler, yazarın cinsiyeti, yıl, tez türü, danışman (sayısı, unvanı, cinsiyeti), kurum (üniversite, enstitü, ana bilim dalı, bilim dalı), çalışma alanı/konusu ile Türkçe ve İngilizce çalışma başlıkları gibi çeşitli bibliyometrik parametreler açısından değerlendirilmiştir. Çalışmanın evreni YÖK Ulusal Tez Merkezi veri tabanında 17 Ocak 2020 itibariyle yer alan, hazırlanmakta olan tezler kategorisindeki 538 turizm konulu lisansüstü tezi kapsamaktadır. Araştırmada veri toplama tekniği olarak nitel araştırma yöntemlerinden doküman-arşiv tarama tekniği kullanılarak ikincil veri kaynaklarından yararlanılmıştır. Erişim sağlanan tezlerin değerlendirilmesinde veri görselleştirme analizi kullanılmış, tezler belirtilen bibliyometrik parametreler açısından çapraz tablolar eşliğinde ele alınarak en çok hangi konulara önem verildiği grafiklerle daha anlaşılır hale getirilmiştir. Araştırma ile 18 Haziran $2018^{\prime}$ de çıkarılan yönetmelik doğrultusunda Türkiye'de hazırlanma aşamasında olan lisansüstü tezlerin ulusal tez veri tabanına girişlerinde önemli oranda bir artışın gerçekleştiği sonucuna ulaşılmıştır.

Anahtar Kelimeler: Turizm Literatürü, YÖK, Lisansüstü Tezler, Veri Görselleştirme, Bibliyometrik Analiz. Makale Gönderme Tarihi: 06.01.2020

Makale Kabul Tarihi: 13.04.2020

\footnotetext{
Önerilen Atıf:

Boyraz, M., Kabakulak, A. ve Mutlu, A. S. (2020). Hazırlanmakta Olan Turizm Konulu Lisansüstü Tezlerin Veri Görselleştirme Tekniği ile Bibliyometrik Analizi: 2006-2020 Yılları Örneği, Türk Turizm Araştırmaları Dergisi, 4(2): 1434-1453.

(C) 2020 Türk Turizm Araştırmaları Dergisi.
} 


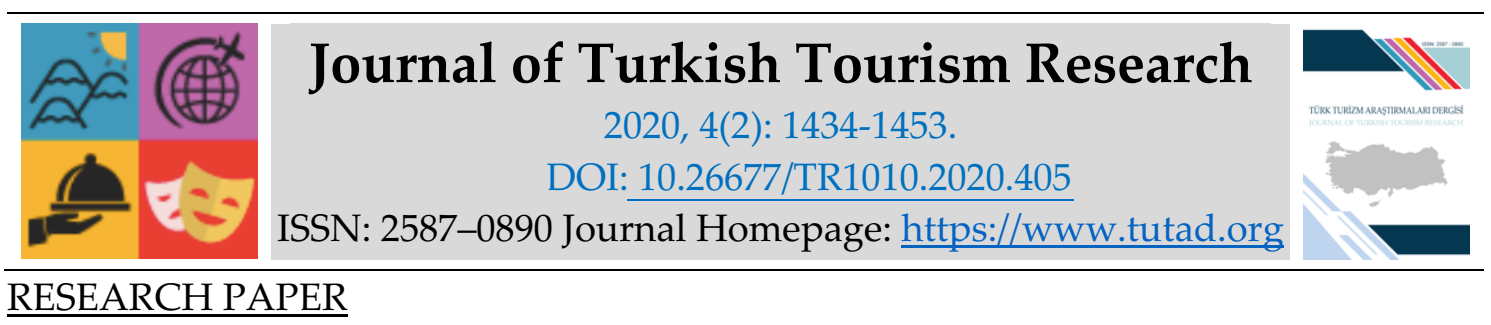

\title{
Bibliometric Analysis of Incomplete Graduate Theses on Tourism with Data Visualization Technique: The Case of 2006-2020
}

Research Assistant Mehmet BOYRAZ, Afyon Kocatepe University, Faculty of Tourism, Afyonkarahisar, e-mail: mboyraz@aku.edu.tr ORCID: https://orcid.org/0000-0001-6755-1999

Research Assistant Ali KABAKULAK, Afyon Kocatepe University, Faculty of Tourism, Afyonkarahisar, e-mail: alikabakulak@aku.edu.tr ORCID: https://orcid.org/0000-0001-9256-8557

Research Assistant Asilhan Semih MUTLU, Afyon Kocatepe University, Faculty of Tourism, Afyonkarahisar, e-mail: smutluc@aku.edu.tr

ORCID: https://orcid.org/0000-0002-5235-7090

\begin{abstract}
The aim of this research is to examine the postgraduate theses on the subject of tourism, which are in the Council of Higher Education (YOK) Thesis Center, by using data visualization technique. Dissertations were evaluated in terms of various bibliometric parameters such as the author's gender, year, thesis type, consultant (number, title, gender), institution (university, institute, major, branch of science), field of study / subject and study titles in Turkish and English. The population of the study covers 538 tourism-related graduate theses in the thesis category that are being prepared as of January $17^{\text {th }}, 2020$ in YOK National Thesis Center database. In the research, secondary data sources were used by using the document-archive scanning technique, which is one of the qualitative research methods, as the data collection technique. Data visualization analysis was used in the evaluation of the accessed theses. Dissertations were discussed in the accompanying bibliometric parameters via cross tables, making it more understandable with the graphics. Preparation stage of 18 June 2018 in accordance with regulations issued in Turkey significantly postgraduate thesis dissertation at the entrance to the national database has reached the conclusion that an increase occurred.
\end{abstract}

Keywords: Tourism Literature, YOK, Postgraduate Theses, Data Visualization, Bibliometric Analysis. Received: 06.01.2020

Accepted: 13.04 .2020

\section{Suggested Citation:}

Boyraz, M., Kabakulak, A. and Mutlu, A. S. (2020). Bibliometric Analysis of Incomplete Graduate Theses on Tourism with Data Visualization Technique: The Case of 2006-2020, Journal of Turkish Tourism Research, 4(2): 1434-1453.

(C) 2020 Türk Turizm Araştırmaları Dergisi. 


\section{Gíriş}

Enstitüler, üniversitelerde birden fazla benzer ve ilgili bilim dallarında lisansüstü, eğitim öğretim, bilimsel araştırma ve uygulama yapan yükseköğretim kurumlarıdır. Bu kurumlarda verilen eğitimlerin başında ise yüksek lisans ve doktora programları gelmektedir. Yüksek lisans eğitim-öğretim ve araştırmanın sonuçlarını; doktora ise orijinal bir araştırmanın sonuçlarını ortaya koymayı amaçlayan bir yükseköğretimdir (Yükseköğretim Kanunu, 2020:3). Bu hedefler doğrultusunda; Yükseköğretim Bilgi Yönetim Sistemi (YÖBYS) 2018-2019 verilerine göre Türkiye'de 702 enstitü, 31104 anabilim dalı, 8026 bilim dalı bulunmakla birlikte 12512 yüksek lisans programı, 5450 doktora programı bulunmaktadır (YÖBYS, 2020). Bu programlar içerisinde dünya turizminin gelişimine paralel olarak turizm alanındaki programlarının sayısında artış görülmektedir. Toplumsal gelişme ve ekonomik kalkınma için gerekli bilimsel araştırmaları yapacak insan gücünü sağlayan lisansüstü eğitim (Tonbul, 2016), turizm alanında farklı anabilim dalları ve bilim dallarında gerçekleştirilmektedir.

Yükseköğretim Kurumu (YÖK) Ulusal Tez Merkezi verilerine göre turizm konusunda 3725'i yüksek lisans ve 962'si doktora düzeyinde olmak üzere toplamda hazırlanmış 4687 lisansüstü tez bulunmaktadır (Yükseköğretim Kurulu Başkanlığı (YÖKB, 2020). Hazırlanan tezlerin taranması araştırmacılar için bilgiye ulaşmak ve konu seçiminde faydalı olmakla birlikte, aynı anda birçok araştırmacının yüksek lisans ve doktora tezi hazırlaması aynı konu üzerinde çalışma ihtimalini ortaya çıkartmaktadır. Bu kapsamda Yükseköğretim Kurumu tarafından "Lisansüstü Tezlerin Elektronik Ortamda Toplanması, Düzenlenmesi ve Erişime Açılmasına İlişkin Yönerge" ile 18 Haziran 2018 tarihi itibariyle tez önerisi kabul edilen yüksek lisans ve doktora programı öğrencilerinin tez konularını Tez Otomasyon Sistemine eklemesi zorunlu hale getirilmiştir (YÖKB, 2020). Böylelikle hazırlanan tezlere yönelik birtakım bilgiler (yazar adı, tez adı, anabilim dalı, konu(lar), danışman adı, kurum adı) YÖK tez veri tabanında paylaşılmaktadır. Bu bilgiler doğrultusunda lisansüstü tezlerdeki güncel araştırma konuları (turizm ve diğer konular) ve araştırma alanları (anabilim dalı, disiplin ve diğer alanlar vb.) dağılımları, araştırmaya konu olan destinasyonlar (ülke, bölge, il, ilçe vb.), benimsenen araştırma yöntemleri (model, metot, analiz türleri vb.) hakkında araştırmacıların bilgi sahibi olması ve çıkarımda bulunabilmesi ile yakın gelecekte yapılması planlanan tez çalışmalarında olası tekrarların önüne geçilmesi mümkün hale gelmiştir. Dolayısıyla hazırlanma sürecindeki lisansüstü tezlerin sistematik olarak incelenerek belirtilen değişkenler açısından mevcut durumlarının ortaya konması, ilerleyen dönemlerdeki tez çalışmalarına kaynak oluşturması ve ışık tutması açısından önem arz etmektedir. Nitekim belirli bir bilim dalı veya disipline ilişkin lisansüstü tezlerin bibliyometrik olarak çözümlenmesi, ilgili disiplin ve alanda iletişimin nasıl gerçekleştiğinin belirlenmesi, bilimsel eğilimin yönünün ortaya çıartılması, teorik gelişim sürecinin takibi ile bilimin geleceğine yön verilmesi açısından önem taşımaktadır (Baytok, Boyraz ve Pelit, 2019). Turizm alanındaki lisansüstü tezlere yönelik yapılan bibliyometrik çalışmaların tamamlanmış tezler üzerine yapıldığı ve hazırlanmakta olan tezlere ilişkin benzer bir çalışma olmadığı gözlenmiştir. Bu noktadan hareketle ilgili yönergeye bağlı olarak turizm alanında otomasyon sistemine eklenmiş hazırlanmakta olan tezlerin çeşitli parametreler (Türkçe ve İngilizce başlıkları, üniversite, enstitü, anabilim dalı, bilim dalı, konu, yazar, danışman, hazırlanma yılı) kapsamında detaylı olarak değerlendirilmesi amaçlanmıştır. 


\section{İLGILII ÇALIŞMALAR}

Belirli bir konuya yönelik alandaki ilgili çalışmaların genel olarak değerlendirilmesinde kullanılan bibliyometrik analiz yöntemi Pritchard (1969:348) tarafından "matematiksel ve istatistiksel yöntemlerin kitaplar ve diğer iletişim ortamlarına uygulanması" olarak tanımlanmaktadır. Belirli bir alanda veya bilim dalında gerçekleştirilen bilimsel araştırmaların incelenmesi ve bunun düzenli olarak tekrar edilmesi, ilgili bilim dalının anlık fotoğrafının çekilmesi, teorik, kuramsal ve kavramsal zenginliğinin tespit edilmesini sağlamaktadır. Bu kapsamda ilgili bilim dalına yönelik kuramsal altyapıda ne gibi değişikliklerin olduğu, ne tür gelişmelerin yaşandığı, nasıl ve ne yönde ilerlediği ortaya çıkartılabilir. Bununla birlikte yeni eğilimlerin neler olduğu ve bu yeni eğilimlere yönelik ne gibi politikalar/stratejiler uygulanması gerektiğine ilişkin strateji sunulabilirken diğer taraftan da ortaya çıkan sorunlara yönelik oluşturulacak tartışma ortamı ile etkili ve rasyonel çözümler üretilebilir. Böylelikle mevcut durum tespiti ile dünü ve bugünü belli olan alanın kendi geleceğine 1şık tutması mümkün hale gelecektir (Baytok vd., 2019:288). Bu noktada, belirli bir alana ait yapılmış olan çalışmaların farklı parametreler açısından profilinin ortaya konulmasında bibliyometri çalışmaları önemli bir araştırma türü olarak önem kazanmaktadır (Al, 2008; Al ve Soydal, 2012). Çünkü bilimsel çalışmaların, yazar, konu, atıf yapılan yazar, atıf yapılan kaynaklar gibi verilerin istatistiksel olarak incelenmesi ile ilgilenen bibliyometri, elde edilen istatistiksel sonuçlar doğrultusunda belirli bir disipline ait genel yapının ortaya konmasını mümkün kılmaktadır (Zan, 2012:15). Dolayısıyla bibliyometri çalışmalarının, akademik açıdan incelendiğinde üretkenliğin ve sürdürülebilirliğin değerlendirilmesinde bir rehber veya yol haritası olduğu söylenebilir. Bu amaçla turizm alanındaki sağlıklı bilgi birikimin artırılması amacıyla hazırlanmakta olan lisansüstü tezlerin incelenerek ileriki araştırmalara altyapı oluşturabilmesi için bu çalışma kapsamında da bibliyometrik analiz yöntemi tercih edilmiştir.

Turizm literatüründe bibliyometrik çalışmaların bildiri, makale, kitap veya tez gibi farklı yayın türlerinde yapıldığı ve bu tür çalışmaların son yıllarda önem kazandığı (Baytok vd., 2019) ortaya konulmuştur. Bu kapsamda turizm alanında hazırlanmış bibliyometrik çalışmalara yönelik incelenen araştırmalar yayın türüne göre ele alınmıştır. Turizm literatüründe belirli bir konuya ilişkin tüm yayın türlerini (tez, makale, kitap, bildiri, araştırma notu vb.) bir arada incelemeye yönelik hazırlanan bibliyometrik bildiri çalışmaları olarak; turizm işletmeciliği (Türktarhan, 2014), turizm pazarlaması (Türktarhan, 2014), kültürel miras (Toksöz ve Birdir, 2016), çevre (Boyraz ve Güvenen, 2017), turizm (Yllmaz ve Toprak, 2017; İpkoparan ve Akbaba, 2019) helal turizm (Olcay, Karaçil ve Sürme, 2017), sosyal medya (Köroğlu, Özkan ve Curkan, 20017), engelli turizmi (Yalın, İlsay ve Avcıkurt, 2014), moleküler gastronomi (Ceylan ve Sarışık, 2018), sürdürülebilir turizm (Erkol Bayram, Bayram ve Karaçar, 2017), planlı davranış teorisi (Nebioğlu ve Kalıpçı, 2019), gastronomi (Alan ve Şen, 2019), turizm festivalleri (Boyacıoğlu ve Elmas, 2019) ve kış turizmi (Çalhan ve Çakıcı, 2019) konuları üzerine araştırmalar yapılmıştır. Bununla birlikte aynı alanda farklı konulara ilişkin sadece yayınlanmış makalelere yönelik gerçekleştirilen bibliyometrik bildiri çalışmaları arasında ise; kış turizmi (Yağcı, Ulusoy, Avcıkurt ve Köroğlu, 2018); turizm (Evren ve Kozak, 2000; Dursun, Bayraktaroğlu ve Kozak, 2018), turizm pazarlamas1 (Özel ve Kozak, 2012), turizm talebi (Aydın, Arslan ve Coşkun, 2016), gastronomi ve yiyecek içecek (Güçlü Nergiz ve Kapucuoğlu, 2018), yerel halk (Yeşilyurt ve Koçak, 2018), turizm rehberliği (Kaygalak Çelebi ve Kırlar, 2019), turist rehberliği (Şahin ve Acun, 2015), turizmde inovasyon (Gül ve Gül, 2018), turizm kongresi (Çakıcı, Yıldırım ve Karacaoğlu, 2014), etik ve 
sosyal sorumluluk (Baytok vd., 2018) ve turizm yıllığı dergisi (Türktarhan ve Kozak, 2012) makaleleri ele alınmıştır.

Turizm alanında çalışmaları konu edinen bibliyometrik makaleler; turizm alanındaki tezler (Büyükşalvarcı ve Keleş, 2019; Tayfun, Küçükgergin, Aysen, Eren ve Özekici, 2016); medikal turizm tezleri (Çolakoğlu, Altun ve Kıykaç, 2019); gastronomi makaleleri (Sandıkcı ve Mutlu, 2019); yiyecek içecek işletmeciliği tezleri (Aydın, 2017); kırsal turizm çalışmaları (Bozok, Kılıç ve Özdemir, 2017); gastronomi tezleri (Sünnetçioğlu, Yalçınkaya, Olcay ve Mercan, 2017; Altaş ve Acar 2018); sağlık turizmi makaleleri (Temizkan, Çiçek ve Özdemir, 2015); sürdürülebilir turizm tezleri (Demirbulat ve Tetik Dinç, 2017); gastronomi alanyazını (Güzeller ve Çeliker, 2017); gastronomi kitapları (Altaş, 2017) kırsal turizm tezleri (Alimanoğlu ve Ayazlar, 2017); yöresel yiyecek tezleri (Ayaz ve Türkmen, 2018); gastronomi anabilim dalı tezleri (Şahin, Akdağ, Çakıcı ve Onur, 2018); helal turizm (Olcay, Karaçil ve Sürme, 2017); kırsal kalkınma (Gül ve Gül, 2018); etik ve sosyal sorumluluk çalışmaları (Baytok vd., 2018); liderlik tezleri (Çelik, 2019); sağlık turizmi tezleri (Canik ve Güneren, 2019); kültürel miras alanyazını (Demiral ve Saatçi, 2019); planlı davranış teorisi (Nebioğlu ve Kalıpçı, 2019) konuları üzerine hazırlanmıştır.

Bildiri ve makalelere yönelik bibliyometrik araştırma sayısının fazla olmasına karşılık turizm alanında bibliyometrik analiz yöntemi ile hazırlanmış tez ve kitap sayısı sınırlıdır. Turizm alanında turizm tezlerinin bibliyografyası kitabı Kozak (1995); gastronomi alanında tez, makale ve bildirilerin bibliyografyası "Gastronomi Araştırmaları Bibliyografyası" kitabı ise, Sandıkcı, Boyraz, Mutlu ve Gökçe (2018) tarafından hazırlanmıştır. Diğer taraftan bibliyometri konusu lisansüstü tezlerde de çalışılmış ve bu kapsamda kültür turizmi çalışmaları Altuntop (2019), yerel halkın bakış açısı ile turizmin etkileri Çıkrık (2018), uluslararası dergilerde yer alan makalelerin bibliyometrisi ile Türkiye turizm literatürünün durumu Altürk (2018) tarafından lisansüstü tezlerde araştırma konusu olarak benimsenmiştir.

Turizm alanında hazırlanmış lisansüstü tezlere yönelik bibliyometrik bildiri çalışmaları; seyahat işletmeciliği (Arıca, 2014), turizm (Güçlü Nergiz, 2014; Civelek ve Türkay, 2017; Kurtgözlü ve Güçlü Nergiz, 2019), kırsal turizm (Alimanoğlu ve Ayazlar, 2017; Kılıç, Oflaz, Mısır ve Hacıŏ̆lu, 2018; Albayrak, Tüzünkan ve Dalkılıç, 2019), gastronomi (Şahin, Akdağ, Çakıcı ve Onur, 2018), örgütsel davranış (Karabacak ve Güçlü Nergiz, 2019), sağlık turizmi (Güneren ve Canik, 2018), kış turizmi (Aymankuy, Oflaz ve Zamantılı, 2018), turist rehberliği (Özsoy ve Çokal, 2018), medikal turizm (Çolakoğlu, Altun ve Kıykaç, 2018), yiyecek içecek işletmeciliği (Aydın, 2014), engelli turizmi (Aksöz ve Yücel, 2019) ve liderlik (Çelik, 2019) konusunda yapılmıştır.

Literatürde yer alan turizm alanındaki bibliyometrik araştırmalara bakıldığında tezlerin ya belirli bir dönem itibariyle ya da turizmin özellikli bir alt bilim alanına ya da konusuna yönelik olarak ele alındığı tespit edilmiştir. Buna karşın hazırlanmakta olan tezlere ilişkin bir çalı̧̧maya rastlanmamıştır. Bu açıdan araştırma, alan yazındaki eksikliğin giderilmesi amacıyla Ulusal Tez Merkezinde hazırlanmakta olan turizm konulu tezlerin değerlendirilmesi üzerine tasarlanmıştır. Böylece turizm konusunda hazırlanması planlanan tezlere ilişkin veri elde edilmesi hedeflenmiştir.

\section{YÖNTEM}

Bu araştırmada, 18 Haziran 2018 tarihinde yürürlüğe giren "Lisansüstü Tezlerin Elektronik Ortamda Toplanması, Düzenlenmesi ve Erişime Açılmasına İlişkin Yönerge" doğrultusunda tez 
önerisi kabul edilen öğrenciler tarafından zorunlu olarak doldurulan tez veri giriş formları kapsamında YÖK Ulusal Tez Merkezi'nde yer alan turizm konulu hazırlanma aşamasındaki lisansüstü tezlerin bibliyometrik olarak incelenmesi amaçlanmaktadır. Bu kapsamda hazırlanmakta olan lisansüstü tezler, yazarın cinsiyeti, yıl, tez türü, danışman (sayısı, unvanı, cinsiyeti), kurum (üniversite, enstitü, ana bilim dalı, bilim dalı), çalışma konusu ile Türkçe ve İngilizce çalışma başlıkları gibi çeşitli bibliyometrik parametreler açısından değerlendirilmiştir.

Çalışmanın evrenini YÖK Ulusal Tez Merkezi veri tabanındaki yer alan hazırlanmakta olan tezler kategorisindeki turizm konulu lisansüstü tezler oluşturmaktadır. Araştırmada veri toplama tekniği olarak nitel araştırma yöntemlerinden doküman-arşiv tarama tekniği kullanılarak ikincil veri kaynaklarından yararlanılmıştır. Bu kapsamda 16-17 Ocak 2020 tarihinde yapılan taramalar sonucunda ulaşılan 538 tane lisansüstü tez çalışması araştırmanın evrenini oluşturmaktadır. Araştırmada tüm tezlere ulaşma imkânı olmasından dolayı tam sayım yöntemi kullanılmış ve tezlerin tümü araştırma kapsamına dâhil edilmiştir. Erişim sağlanan tezlerin değerlendirilmesinde sıklık ve yüzde analizi birlikte kullanılmış ve tezler belirtilen bibliyometrik parametreler açısından çapraz tablolar halinde ele alınmıştır. Bununla birlikte tez başlıkları hem Türkçe hem de İngilizce olarak ayrı ayrı veri analizine tabi tutulmuş ve veri görselleştirme araçlarından Tableau ile incelenmiştir. Böylelikle tezlerde en çok hangi konulara önem verildiği grafiklerle daha anlaşlır hale getirilmiştir.

Araştırma ile 17 Ocak 2020 tarihi itibariyle YÖK Ulusal Tez Veri Merkezi'nde kayıtlı Türkiye'de turizm konulu 450'si yüksek lisans ve 132'si doktora düzeyinde olmak üzere toplamda 582 lisansüstü tezin hazırlanıyor/yazım aşamasında olarak listelendiği görülmüştür. Bu çalışmalara yönelik yazar isimlerine göre yapılan ikincil kontroller sonrasında, 6 'sı doktora ve $38^{\prime}$ i yüksek lisans düzeyinde olmak üzere 44 tezin daha önce tamamlanmış olmasına rağmen hala hazırlanıyor şeklinde bu sınıflandırmanın içinde aktif olarak yer aldığı tespit edilmiştir. Dolayısıyla tamamlanmış olan 44 tez, çalışmanın kapsamı dışında tutulmuştur.

\section{BULGULAR}

Araştırma ile Türkiye'de 17 Ocak 2020 tarihi itibariyle turizm konulu 538 lisansüstü tezin hazırlanmakta olduğu belirlenirken, bunların \%77'si yüksek lisans ve \%23'ü doktora düzeyindedir. Cinsiyet bakımından tezleri hazırlayan yazarlarının \%66,5'i erkek iken 33,5'i kadındır. Yürütülen tezlerin $\% 96,4^{\prime}$ üne tek öğretim üyesi danışmanlık yaparken $\% 1,7^{\prime}$ si iki ve $\% 1,9^{\prime} \mathbf{u}$ ise üç ayrı öğretim üyesinin danışmanlığında hazırlanmaktadır. Tez danışmanları (ilk) unvanlarına göre $\% 26,7$ ile profesör doktor, 37,2 ile doçent doktor ve $\% 36,1$ ile doktor öğretim üyesi şeklinde dağılım göstermektedir.

Tablo 1'de tezlerin veri sistemine giriş tarihlerine/yıllara ve yazarların cinsiyetlerine göre dağılımlarına yer verilmiştir. Hazırlanan tezlerin en eski tarihli olanları 2006 yılında ilk defa sisteme girişi yapılmıştır. YÖK veri tabanına tez girişleri, 18 Haziran 2018 tarihinde yürürlüğe giren yönetmelik doğrultusunda tez önerisi kabul edilen öğrenciler tarafından tez veri giriş formlarının doldurulmasının zorunlu hale gelmesine paralel olarak aynı yılın sonlarında artış göstermiş ve 2019 yılında 333 adet ile en üst düzeye yükselmiştir. Bununla birlikte lisansüstü eğitimde azami tamamlama süresi yüksek lisans programları 6 ve doktora programlarında 12 yarıyıl (Lisansüstü Eğitim ve Öğretim Yönetmeliği, 2016) olmasına rağmen YÖK veri tabanında 2020 yılı itibariyle bu süreçlerden daha uzun bir dönemdir (2006-2008-2009-2015) tezlerin hala hazırlanmakta olarak sınıflandırıldığı tespit edilmiştir. 
Tablo 1. Yıllara Göre Tez Türü ve Yazar Cinsiyetlerinin Dağılımı

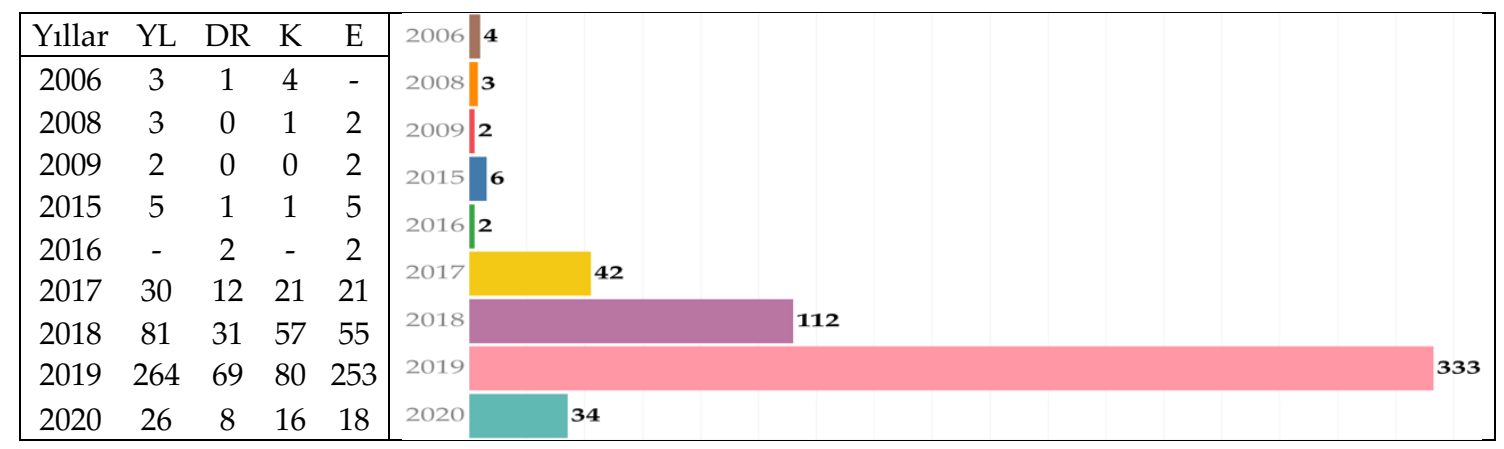

YL: Yüksek Lisans, DR: Doktora, K: Kadın, E: Erkek, \#: Toplam

Tezlerin hangi enstitü bünyesinde hazırlandığına yönelik dağılımlar Tablo 2' de detaylı olarak ele alınmıştır. Bu doğrultuda turizm konulu tezlerin yedi ayrı enstitü bünyesindeki ana bilim veya bilim dallarında hazırlık aşamasında olduğu, bunlar arasında yaklaşık \%90 ile Sosyal Bilimler Enstitülerinin öne çıktı̆̆ı, onu \%7,43 ile Lisansüstü Ĕ̆itim Enstitülerinin takip ettiği belirlenmiştir.

Tablo 2. Tezlerin Enstitülere Göre Dağılımı

\begin{tabular}{|c|c|c|c|}
\hline Enstitü Türü & $\mathrm{f}$ & \multirow{3}{*}{$\begin{array}{l}\text { Sağlık Bilimleri } \\
0,93 \%\end{array}$} & \multirow{2}{*}{$\begin{array}{l}\text { Fen Bilimleri } \\
0,93 \%\end{array}$} \\
\hline Sosyal Bilimler & 484 & & \\
\hline Lisansüstü Eğitim & 40 & & $\begin{array}{l}\text { Güvenlik Bilimleri } \\
0,37 \%\end{array}$ \\
\hline Fen Bilimleri & 5 & Lisansüstü Eğitim & Dıș Ticaret \\
\hline Sağlık Bilimleri & 5 & & $0,19 \%$ \\
\hline Güvenlik Bilimleri & 2 & Sosyal Bilimler & $\begin{array}{l}\text { Akdeniz Uygarlıkları Araştırma } \\
0,19 \%\end{array}$ \\
\hline Akdeniz Uygarlıkları & 1 & $89,96 \%$ & \\
\hline Araştırma & & & \\
\hline Dış Ticaret & 1 & & \\
\hline
\end{tabular}

Tezler hazırlandıkları ana bilim dallarına (ABD) göre incelendiğinde 26 teze ilişkin YÖK veri tabanında herhangi bir bilgi yer almazken geriye kalan 512 tezin 44 ayrı ana bilim dalı ile bunlar altında yer alan 32 bilim dalında hazırlandığı tespit edilmiştir. Tezlerin ait olduğu ana bilim dallarına göre dağılımına grafik 1 'de yer verilmiştir. Bu kapsamda tezlerin en çok $\% 56,8$ ile alan adı ile özdeşleşen Turizm İşletmeciliği ABD'de hazırlanıyor olduğu, onu \% \%9,8 ile Gastronomi ve Mutfak Sanatları ABD ve \%9,6 ile Turizm İşletmeciliği ve Otelcilik ABD'nin takip ettiği görülmektedir. Bununla birlikte ilk $10 \mathrm{ABD}$ incelendiğinde, sekizi doğrudan turizm ve çeşitleri (turizm işletmeciliği, gastronomi ve mutfak sanatları, turizm işletmeciliği ve otelcilik, turizm rehberliği, rekreasyon yönetimi, konaklama işletmeciliği, turizm, seyahat işletmeciliği) ile ilgili olup bunların dışında yalnızca İşletme ABD ve İktisat ABD yer almaktadır. Ayrıca turizm konulu tezlerin turizm ve işletme dışında çok çeşitli (beden eğitimi, coğrafya, cumhuriyet tarihi, grafik, güvenlik stratejileri ve yönetimi, halkla ilişkiler, ilköğretim, iş güvenliği ve sağhl̆̆̆, kadın çalışmalar ve toplumsal cinsiyet, kamu yönetimi ve siyaset vb.) ABD'lerde de hazırlandığı belirlenmiştir. 


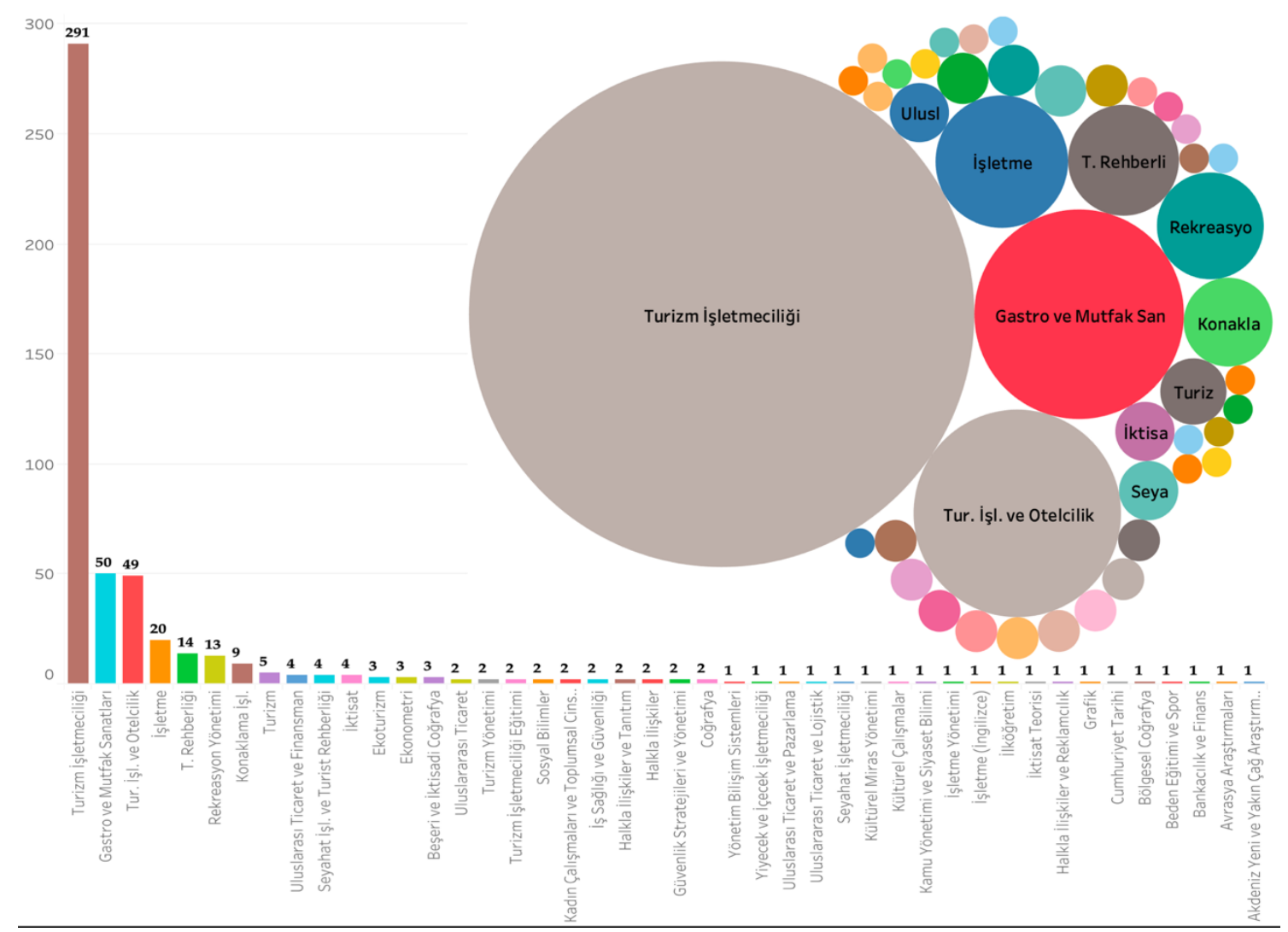

Grafik 1. Tezlerin Ana Bilim Dallarına Göre Dağılımı

Şekil 1'de tezlerin hangi üniversite bünyesinde hazırlandığı, bu üniversitelerde kaç farklı öğretim üyesinin hazırlanan tezlere danışmanlık yaptığı ve üniversitelerde öğretim üyesi başına kaç farklı tez yönetildiğine ilişkin görsel analiz bulgularına yer verilmiştir. Tezlerin 58 ayrı üniversite bünyesinde hazırlandığı belirlenmiştir. Şekildeki her bir daire kurum olarak bir üniversiteyi temsil etmekte olup, dairelerin çapı ilgili üniversitelerin belirtilen değişken bakımından ağırlıklarını görsel olarak vurgulamaktadır. Verilerin görselleştirmesinde sadece en belirgin ve öne çıkan ilk 10 kurum baskın hale getirilmiştir. Bu kapsamda ilk olarak hazırlanan tez sayısı bakımından 112 ile Akdeniz, 82 ile Nevşehir Hacı Bektaş Veli ve 45 ile Balıkesir Üniversitelerinin ilk üç sırada yer aldığı, bu üç kurum tarafından hazırlanan tezlerin toplam içerisindeki payının $\% 44,4$ olduğu ortaya çıkmıştır. Bu üniversitelerin yanı sıra Ankara Hacı Bayram Veli, Atatürk, Afyon Kocatepe, Anadolu, Erciyes ve Süleyman Demirel Üniversitelerinde de önemli sayıda turizm konulu lisansüstü tezlerin hazırlık aşamasında olduğu, ilk 10'da yer alan üniversitelerin toplam içerisindeki tez hazırlık oranı \%70,8 olarak hesaplanmıştır.
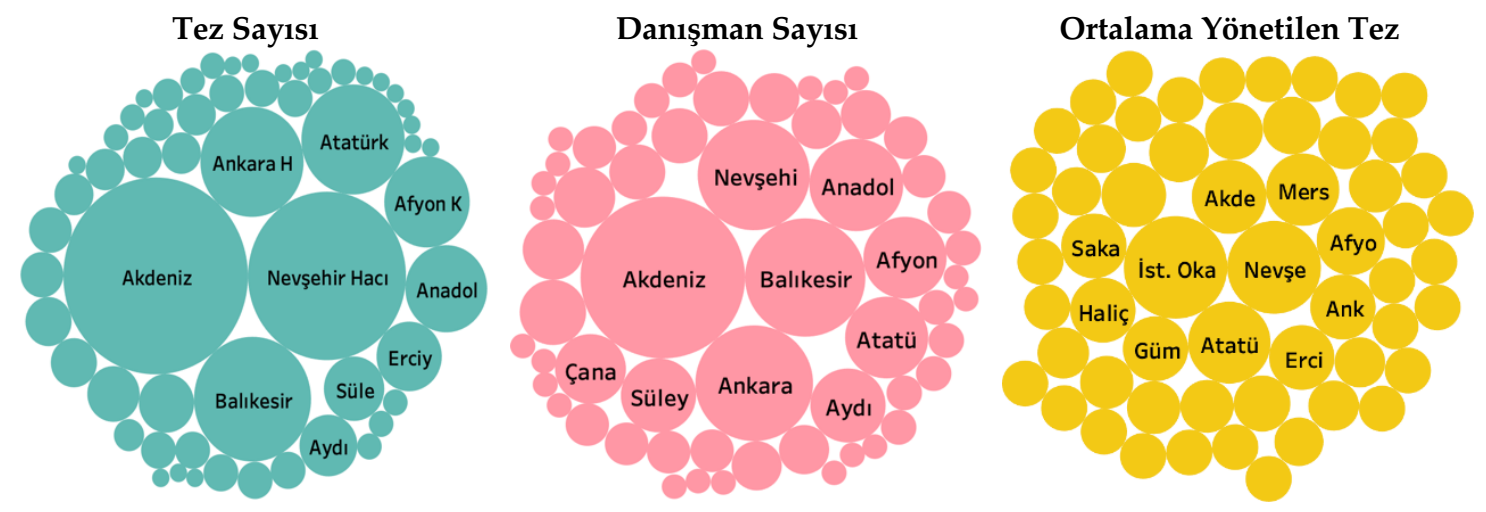

Şekil 1: Üniversitelere Göre Tez, Danışman ve Ortalama Yönetilen Tez Sayısı 
Üniversiteler tezlere danışmanlık yapan öğretim üyesi sayısı bakımından değerlendirildiğinde, tez sayısına yönelik analiz sonuçları ile benzer bir durum ortaya çıkmakta olup, tez sayısı açısından ilk 10'da yer alan Erciyes Üniversitesi'nin yerine danışman sayısı bakımından Aydın Adnan Menderes Üniversitesi'nin sıralamayı değiştirdiği görülmüştür. Tezlerin hazırlanmasında 285 farklı öğretim üyesi tarafından danışmanlık yürütüldüğü belirlenmiştir. Danışman sayısı bakımından 43 ile Akdeniz, 23 ile Balıkesir ve 22 ile Ankara Hacı Bayram Veli Üniversitelerinin ilk üç sırada yer aldığı, bu üç kurumdaki öğretim üyelerinin tezlere danışmanlık yapan toplam öğretim üyesi içerisindeki çeşitliliği \%30,9'dur. Bir diğer değişken olarak üniversitelerdeki öğretim üyeleri tarafından yönetilmekte olan turizm konulu tez sayısı bakımından en çok 5,0 ile İstanbul Okan, 4,10 ile Nevşehir Hacı Bektaş Veli ve 3,18 ile Atatürk Üniversiteleri ilk üç sırada yer almaktadır. Bu üniversiteleri Akdeniz $(2,60)$, Mersin $(2,50)$ ve Afyon Kocatepe $(2,18)$ Üniversiteleri takip etmektedir.

Yönetilen tez sayısı bakımından danışman öğretim üyeleri ile en fazla tez yöneten danışmanlar grafik 2' de değerlendirilmiştir. Öğretim üyelerinin 1 ile 10 arasında değişen sayıda turizm konulu tezlere ilişkin danışmanlık yaptığı, danışman başına ise ortalama 1,89 tezin hazırlık aşamasında yer aldığı tespit edilmiştir. Bu kapsamda öğretim üyelerinin 176 's1 $(\% 61,8)$ tarafından sadece birer teze ilişkin danışmanlık yürütülürken, en fazla tez yönetmekte olan ilk 12 öğretim üyesinin $(\% 4,2)$ hazırlanmakta olan tüm tezlerin \%17,3'üne danışmanlık yapmakta olduğu belirlenmiştir. En fazla tez yönetmekte olan danışmanların kurumları incelendiğinde yine Akdeniz, Nevşehir Hacı Bektaşi Veli ve Atatürk Üniversitelerinin ön plana çıktığı görülmektedir.

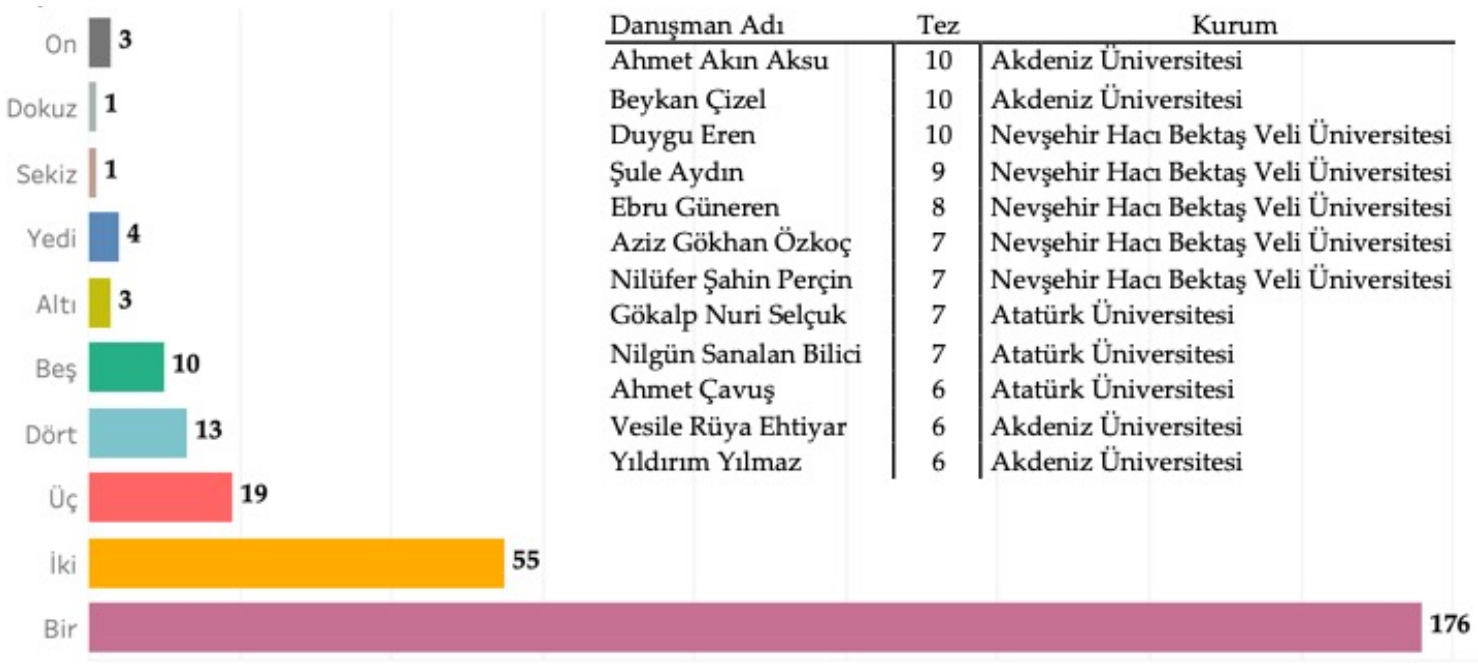

Grafik 2. Yönetilen Tez Sayısına Göre Danışman Sayısı ve En Fazla Tez Yöneten Danışmanlar

Araştırmanın ikinci aşamasında, hazırlanmakta olan tezlerin başlıkları incelenmiş ve kullanılan sözcükler genelden özele çeşitli gruplandırmalarla görselleştirilmiştir. Bu kapsamda ilk olarak tez başlıklarında herhangi bir gruplandırma/sınıflandırma veya eleme yapılmadan Türkçe ve İngilizce en çok tekrar eden sözcükler karşılaştırmalı olarak analiz edilmiştir (Şekil 2). Veri analizinde rakamlar, edat, bağlaç ve sözcük ekleri dikkate alınmamıştır. Türkçe ve İngilizce sözcük haritaları incelendiğinde başlıklarda kullanılan sözcüklerin büyük oranda benzerlik gösterdiği, fakat belirli bir takım farklılıkların da söz konusu olduğu görülmektedir. 

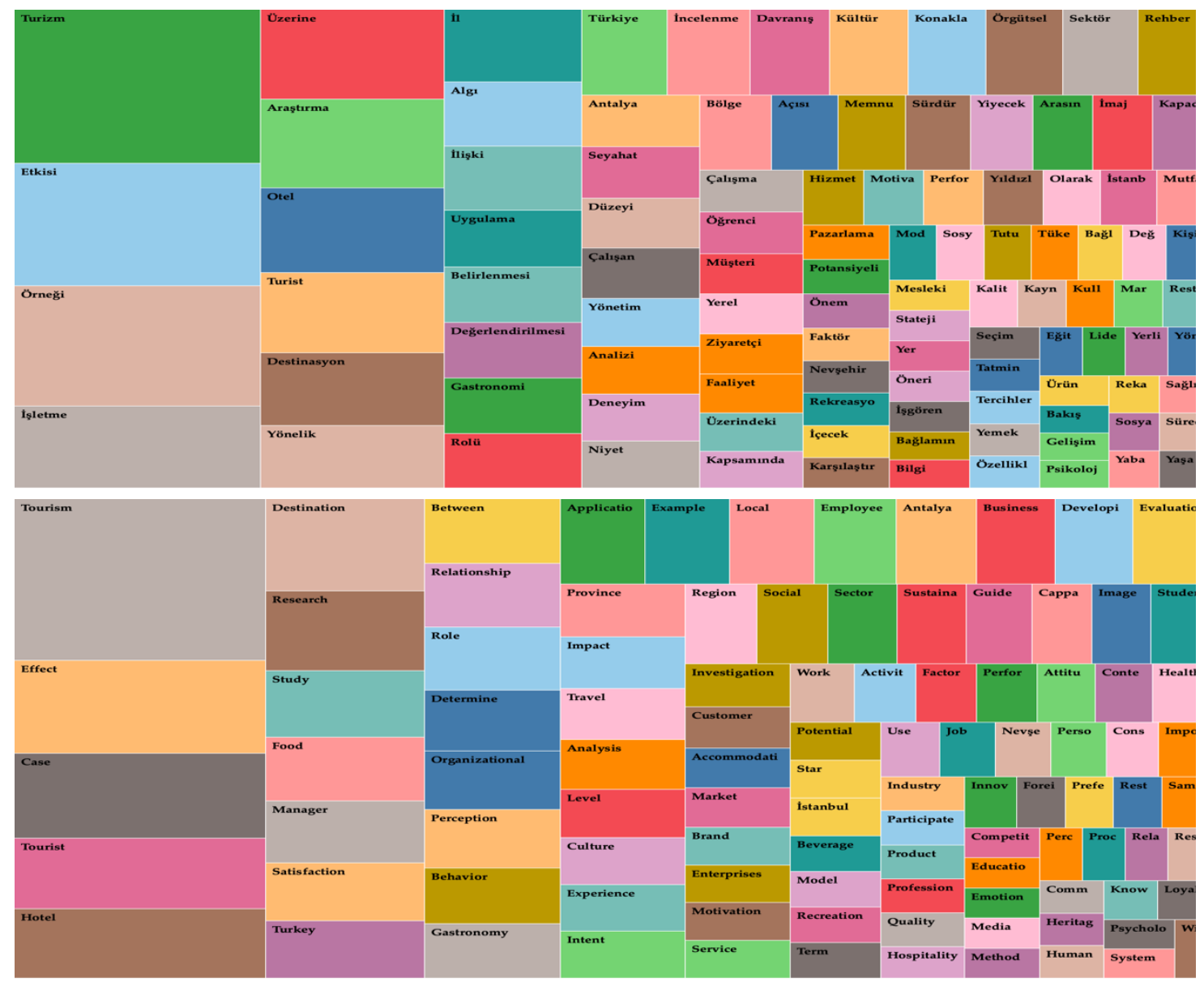

Şekil 2. Tez Başlıklarında Yer Alan Türkçe ve İngilizce En Çok Kullanılan 100 Sözcük

Tezlerin Türkçe başlıklarındaki sözcükler birbirleri ile ilgili konular/alanlar doğrultusunda gruplandırılarak görsel olarak analiz edilmiştir. Bu gruplardan ilk ikisi turizm ve çeşitleri ile turizm destinasyonlarıdır. Grafik 3'de bu iki gruba yönelik ilgili sözcüklerden oluşturulan görsel haritalara yer verilmiştir. Bu kapsamda tezlerde turizm ve çeşitleri ile ilgili 67 ayrı sözcügü̆n toplamda 1277 defa tekrar edildiği, bunlar arasında en fazla otel, turist, destinasyon, gastronomi, kültür, konaklama, rehber, seyahat, deneyim, yiyecek kavramlarının öne çıktığı belirlenmiştir. İkinci olarak tez başlıklarında çalışmanın yapılacağı alanının bir göstergesi niteliğinde destinasyon(lar) kapsamında turizm merkezleri kendi içerisinde bir arada değerlendirilmiş ve görsel analizi yapılmıştır. Aynı il sınırları içerisinde yer alan farklı turizm merkezleri ayrı ayrı değerlendirilmiş, il ve ilçe adı olarak eş zamanlı vurgulanan destinasyonlar bir defa dikkate alınmış, tekrar eden çift sözcükler elenmiştir. Başlıklarda toplam 104 farklı turizm merkezi/destinayona yönelik 337 defa vurgu yapılmıştır. Tezlerin 11'inde iki, dokuzunda üç, birisinde dört ve birisinde altı farklı destinasyon bir arada incelenmekte, geri kalan 278'inde ise birer destinasyon tez başlı̆̆ında yer almaktadır. En çok vurgu yapılan destinasyonlar arasında 50 ile Türkiye, 36 ile Antalya ve 25 ile Kapadokya ilk üç sıradadır. Onları sırasıyla 18 ile İstanbul, 16 ile Nevşehir, 10'ar adet ile Afyonkarahisar ve Erzurum, 9 adet ile Alanya ve 8 adet ile Ankara destinasyonları takip etmektedir. 


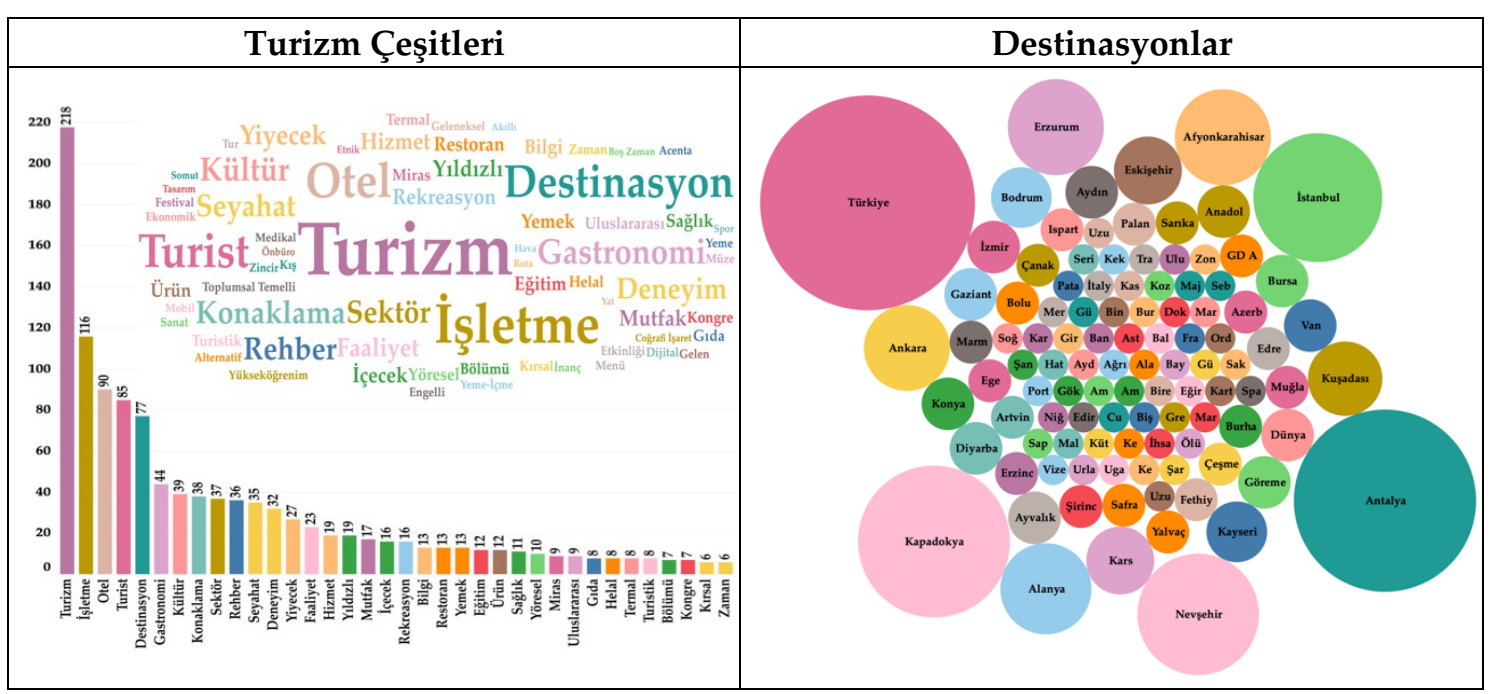

Grafik 3. Tez Başlıklarındaki Turizm ve Destinasyonla İlgili Sözcüklerin Analizi

Tez başlıklarındaki sözcükleri görsel analiz için bir diğer grup değişkenleri olarak araştırma yöntemleri, çalışma örneklemi ve çalışma alanı sınıflandırmalarına tabi tutulmuştur. Bu doğrultuda elde edilen görsel haritalara şekil 3'de ayrıntılı olarak yer verilmiştir. Grafik 3'teki destinasyon sözcüklerine paralel olarak çalışma alanına yönelik tez başlıklarında 11 ayrı sözcügün 163 defa kullanıldığı, bunlar arasında en fazla il ve bölge sözcüklerinin kullanıldığ1 ortaya çıkmıştır. İkinci olarak tez başlıklarında araştırma yöntemlerine yönelik 23 ayrı sözcüğün 482 defa vurgulandığı, bunlar arasında en çok 174 ile etkisi, 51 ile ilişkisi, 43 ile rolü sözcüklerinin tekrar edildiği belirlenmiştir. Bu kavramlarla ilişkili olarak düzeyi, arasındaki, üzerindeki, aracı, düzenleyici gibi sözcüklerin de sıklıkla tez başlıklarında kullanıldığı görülmektedir. Örneklem açısından ise başlıklarda tezlerin 18 ayrı grup üzerinde yoğunlaştı̆̆ı ve bu kapsamda toplamda 212 vurgunun yapıldığ saptanmıştır. Tezlerin en çok 34 ile çalışanlara (turizm işletmeleri), 25 ile öğrencilere ve $24^{\prime}$ er ile müşterilere ve ziyaretçilere yönelik hazırlanmakta olduğu anlaşılmaktadır.

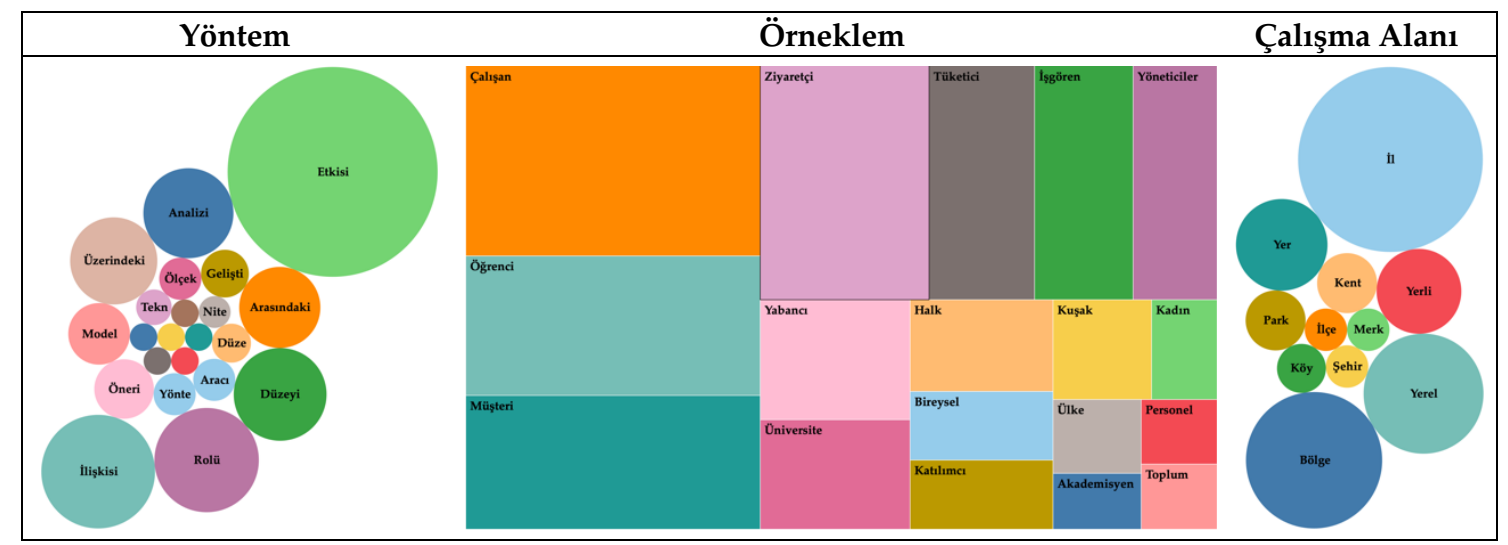

Şekil 3. Tez Başlıklarındaki Yöntem-Örneklem-Çalışma Alanı ile ilgili Sözcüklerin Analizi

Araştırmada son olarak tez başlıklarındaki sözcükler çalışma yapılan konu ve alanları belirlemeye yönelik görsel analiz gerçekleştirilmiş ve elde edilen sonuçlar Grafik 4'te ele alınmıştır. Bu kapsamda yönetim ve organizasyon alanında 81 sözcük 764 defa, pazarlama ile ilgili 10 sözcük 112 kere ve sürdürülebilirlik ile alakalı 8 sözcük 60 defa tekrar edilmiştir. Yönetimle ilgili en çok algı, örgütsel davranış, niyet, memnuniyet, performans, motivasyon, tutum, 
strateji, değer, bağlllık ve tatmin sözcükleri başlıklarda yer alırken, pazarlama alanında ise en fazla imaj, marka, tercih, rekabet ve sosyal medya kavramları kullanılmıştır. Sürdürülebilirlik konusunda ise en çok kavramın kendisi ile birlikte çevre, ekoturizm, enerji, taşıma kapasitesi sözcükleri tez başlıklarında yer almaktadır.

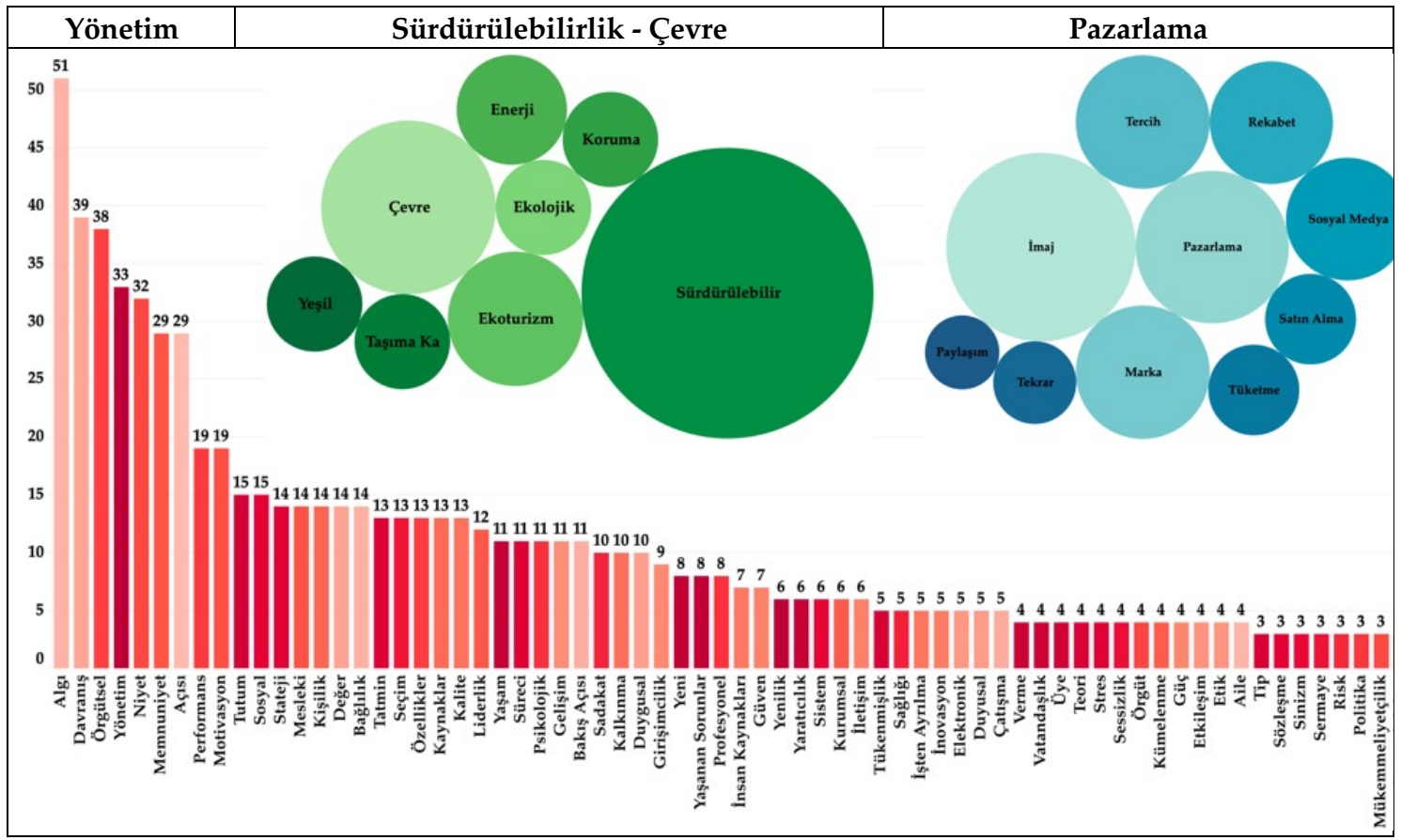

Grafik 4. Tez Başlıklarındaki Sözcüklerin Konulara Göre Dağılımları

Araştırma elde edilen bu bulguların yanı sıra birtakım önemli sınırlılıklara da sahiptir. Bunlardan ilki çalışma evrenini hazırlanma aşamasındaki turizm konulu lisansüstü tezlerin oluşturması ve örneklemini ise sadece YÖK tez veri merkezi formuna girişleri yapılan tezleri kapsaması, tez önerisi kabul edilmesine rağmen henüz bu sisteme girişleri yapılmamış olan tezlerin çalışmaya dâhil edilememiş olmasıdır. İkincisi ise YÖK tez veri merkezinde yer alan hazırlanmakta olan tezlere yönelik bilgi formunun yazar adı, Türkçe/İngilizce tez adı, kurum ve danışman bilgileri ile sınırlı olması ve özet bilgiler, anahtar kelimeler ve içerik hakkında detaylı açıklamaların bulunmamasıdır. Dolayısıyla araştırmada incelenen alanla ilgili değişkenlere (turizm çeşitleri, destinasyonlar, yöntem, örneklem, çalışma alanı, yönetim, sürdürülebilirlik-çeore, pazarlama) yönelik analiz ve çıkarımlar sadece Türkçe tez başlıklarına dayanarak gerçekleştirilebilmiştir. Bu kapsamda elde edilen verilerin/bilgilerin sınırlı olması nedeniyle çalışmada ele alınabilecek değişkenler ile bunlara yönelik gerçekleştirilen görsel analizler de bu sınırlar doğrultusunda değerlendirilebilmiştir.

\section{TARTIŞMA, SONUÇ VE ÖNERİLER}

Yüksek Öğretim Kurulu (YÖK) Ulusal Tez Merkezi'nde yer alan turizm konulu hazırlanmakta olan lisansüstü tezlerin veri görselleştirme tekniği ile çeşitli parametreler açısından incelendiği bu çalışmada birtakım önemli sonuçlara ulaşılmıştır. Bunlardan ilki tezleri yöneten danışman öğretim üyelerinin unvan bakımından en fazla doçent doktor olmasıdır. Bu durum alanyazındaki çalışmaların sonuçlarına göre farklılık göstermektedir. Tayfun vd., (2016) ile Tekin'in (2016) araştırmalarında lisansüstü tezleri yöneten danışmanlar daha çok doktor öğretim üyesi (yardımcı 
doçent) unvanına sahiptir. Bu durum 2001 yılında Üniversiteler Arası Kurul (ÜAK) tarafından alınan karar doğrultusunda turizm akademisyenlerinin turizm alanından doçentlik başvuru hakları kaldırılması ve 2011 yılına kadar geçen 10 yıllık süreç içerisinde turizm alanından doçentlik unvanı alınamaması nedeniyle bu alanda görev yapan akademisyenlerin unvanlarını yükseltememesinden kaynaklanmaktadır. Bu noktadan hareketle bu 10 yıllık dönemde doçentlik başvurusu yapabilecek duruma gelen öğretim üyelerinin 2011 yılından sonra doçent unvanına sahip olma oranının artmasına paralel olarak tezlerdeki nicelik bakımından danışmanlık görevleri de artmıştır.

Yıllara göre tez türü incelendiğinde en fazla $(\% 77,0)$ yüksek lisans tezinin yazıldığı saptanmıştır. Bu sonuç gerek YÖK Tez Merkezi'ndeki turizm konulu lisansüstü tezler içerisindeki yüksek lisans tezlerinin payı $(\% 79,5)$ ile gerek literatürdeki Nergiz (2014), Tayfun vd., (2016) ve Tekin (2016) tarafından yapılan çalışmaların sonuçları ile benzerlik göstermektedir. Tezlerin yazıldığı enstitülere göre dağılımları incelendiğinde en fazla tezin sosyal bilimler enstitüsünde yazılmakta olduğu, Nergiz (2014) ve Tekin'in (2016) çalışmasının sonucu ile araştırmanın sonucu örtüşürken Tayfun vd., (2016) tarafından yapılan çalışmanın sonucunda en fazla çalışmanın eğitim bilimlerinde yazıldığı ortaya çıkmış ve bu sonuç çalışmanın bulgularıyla ters düşmüştür. Turizm alanında tezlerin en fazla sosyal bilimler alanında yazılmış olması Turizm'in sosyal bilimler bünyesinde yer almasından kaynaklandığı dolayısıyla bu sonucun doğal bir durum olduğu ifade edilebilir. Tezlerin anabilim dalı açısından en fazla turizm işletmeciliği anabilim dalında, onu takiben de turizm işletmeciliği ve otelcilik anabilim dalında hazırlandığı belirlenmiştir. Nergiz (2014) ve Tekin'in (2016) çalışma sonuçları bu değişken açısından da ortaya çıkan durumu desteklemektedir. Ayrıca turizm alanının birçok disiplinden beslenen disiplinler arası bir yapısının olduğu (Jafari ve Ritchie, 1981), farklı anabilim dallarında ve farklı disiplinlerde (beden eğitimi, coğrafya, cumhuriyet tarihi, grafik, güvenlik stratejileri ve yönetimi, halkla ilişkiler, ilköğretim, iş güvenliği ve sağlı̆̆l, kadın çalışmaları ve toplumsal cinsiyet, kamu yönetimi ve siyaset vb.) çokça çalışılmakta önemli bir disiplin olduğu ortaya çıkan bir diğer önemli sonuçtur.

Üniversitelerde yazılmakta olan turizm konulu tez sayıları bakımından en fazla Akdeniz, Nevşehir Hacı Bektaş Veli ve Balıkesir üniversitelerinde tezlerin yazıldığı tespit edilmiş olup bu sonuç Tekin'in (2016) bulgusuyla kısmen uyumlu iken Nergiz'in (2014) bulgusuyla benzeşmemektedir. $\mathrm{Bu}$ durumun ortaya çıkmasında turizm lisansüstü eğitimde belirtilen üniversitelerin öncü olması, bu düzeydeki eğitime diğer üniversitelerden çok daha önce başlaması, bünyesinde turizmle ilgili çok fazla ana bilim dalı ile bilim dalında aktif olarak lisansüstü eğitime devam etmesi, Nevşehir Hacı Bektaş Veli Üniversitesi özelinde ise Turizm Araştırmaları Enstitüsü'nün kurulması gibi çeşitli temel faktörler yer almaktadır. Gazi, Dokuz Eylül, İstanbul, Anadolu gibi üniversitelerde de uzun süredir turizm lisansüstü eğitimi verilmesine rağmen gerek turizm alanındaki ana bilim dalı ile bilim dallarının sayısının azlığı gerek danışmanlık yürüten öğretim üyesi sayılarının fazla olması nedeniyle hazırlanmakta olan tezler içerisindeki kurum payları düşük çıkmıştır.

Öğretim üyesi başına düşen ortalama yönetilmekte olan turizm konulu tez danışmanlığı sayısı bakımından karşılaştırıldığında en çok İstanbul Okan, Nevşehir Hacı Bektaş Veli ve Atatürk Üniversiteleri ilk üç sırada yer almaktadır. Bu üniversiteleri Akdeniz, Mersin ve Afyon Kocatepe Üniversiteleri takip etmektedir. Bu durum üniversitelerde ilgili ana bilim dallarında görev yapan akademisyenlerin sayısı ile bu ana bilim dallarına ayrılan/kabul edilen öğrenci kontenjanların/sayıların benzer oranda seyretmediğine veya tezlerin yönetilmesine ilişkin danışman öğretim üyesi atamalarında sistematik hareket edilmediğine işaret etmektedir. Nitekim araştırma kapsamında ulaşılan önemli bulgulardan biri olan "Akdeniz ve Nevşehir Hacı Bektaş Veli Üniversitelerindeki öğretim üyelerinin 10'ar adet tez danışmanlığının bulunması" belirtilen görüşü desteklemektedir. Diğer taraftan pozitif olarak öğretim üyesine başına 1'e yakın ortalama 
tez düşen üniversitelerdeki danışmanların diğerlerine göre daha disiplinli çalıştıkları, öğrencileriyle iletişiminin aktif ve güçlü olduğu, çalışma plan ve süreçlerini daha iyi organize ettikleri ve uyguladıkları, bunun sonucunda da verimli bir çalışma ortamı yakaladıkları ve tez yazım süreçlerini daha iyi yönettikleri ifade edilebilir.

Hazırlanmakta olan tezlerde turizm ve çeşitleri ile en fazla otel, turist, gastronomi, kültür, konaklama, rehberlik, seyahat, deneyim, yiyecek, mutfak, rekreasyon, sağllk, helal, termal, kırsal, kış, engelli gibi tema ve kavramların öne çıktığı belirlenmiştir. Kültür ve Turizm Bakanlığının “2023 Türkiye Turizm Stratejisi" kapsamında belirlemiş olduğu gastronomi, sağlık, kültür, bisiklet, inanç turizmi çeşitlerine doğru bir yönelimin olduğu, Konaklama tesislerinde de mevcut arzın iki milyona çıkarılması gibi hedeflerin olması hazırlanmakta olan tezlerin konularının da bu yönde gelişmesine neden olmaktadır. Dolayısıyla bu hedeflere ulaşabilmek için çeşitli turizm türlerine ilişkin tezlerin yazılması ve planlamaların yapılmasına, destinasyonların eksikliklerin giderilmesinde, kültür ve gastronomi turizmi gibi turizm çeşitlerinin daha iyi uygulanabilmesinde, bu turizm çeşitlerine yönelik arz kaynaklarının uygun ve hazır hale getirilmesinde yol gösterici olabilecektir. Bununla birlikte destinasyon ile ilgili hazırlanmakta olan tezlerde en fazla il ve bölge sözcüklerinin ortaya çıkması destinasyonların artık sadece makro bazda (ülkeler, bölgeler vd.) değil aynı zamanda mikro (il, ilçe, belde vd.) bazda da incelendiğine kanıt oluşturmaktadır. Ayrıca araştırma kapsamında rehberlikle ilgili hazırlanmakta olan tezlerde çalışmaların sayısının arttığı görülmektedir. Nitekim Baytok, Boyraz ve Kabakulak'ın (2019) çalışmasında da belirttiği gibi rehber akademisyenlerin sayısı istenilen seviyeye gelmemiş olmasına rağmen turizm/turist rehberliğine olan ilgi artmaktadır. $\mathrm{Bu}$ kapsamda turizm rehberliği bölümlerinin lisans düzeyinde alt yapısının tamamlanmak üzere olduğu ve buna bağlı olarak da gelecekte turizm rehberliği anabilim dallarında lisansüstü eğitim veren kurum sayısının ve çalışmaların daha fazla olacağı öngörülmektedir.

Hazırlanmakta olan tezlerde en çok etki, ilişki, rol, düzey, analiz, model sözcüklerinin tekrar edildiği belirlenmiştir. $\mathrm{Bu}$ durum, turizm alanındaki tezlerde genellikle konular veya değişkenler arasındaki neden-sonuç ilişkisine yönelik bir durumun saptanmasına, yönetimle ilgili değişkenler arasındaki ilişki ve etkinin yarattığı bağlantıların ve sonuçların ortaya konmasına yönelik çalışmaların daha yaygın olarak benimsendiğinin göstergesidir. Ayrıca yapılması düşünülen iyileştirme ve gelişmelerin de sürekliliğini sağlaması açısından önemli bir ipucu verebilmektedir. Araştırma ile tezlerin örneklemine yönelik ulaşılan sonuçların Tekin (2016) ve Şalvarcı'nın (2019) çalışmalarında ortaya çıkn ve en çok üzerine araştırma yapılan gruplar (çalışanlar, öğrenciler, müşteriler ve ziyaretçiler) açısından incelendiğinde büyük oranda benzerlik gösterdiği anlaşılmaktadır. Araştırma sonucunda ortaya çıkan bir diğer önemli sonuç tezlerde en fazla yönetim ve organizasyon alanında çalışmaların yapıldığıdır. Benzer bir sonuç Karagöz ve Yüncü (2013), Tekin (2016), Tayfun vd., (2016) ile Güzeller ve Çeliker'in (2018) çalışmalarında da rastlanmıştır. Bu durumun ortaya çıkmasında bir hizmet sektörü olan turizmde makineleşme ve otomasyonun çok az olması ve hizmeti alanın da verenin de insan olması etkendir. Bu nedenle insan unsuru ön plandadır. Dolayısıyla işgörenlerin psikolojik tatminleri, mesleki tutumları, yaşam doyumları, kariyer yapma istekleri, örgütsel ve mesleki bağlılıkları gibi psiko-sosyal faktörlerin araştırılması işletmelerin verimliliği, sürdürülebilirliği, karlılığı vb. için bu faktörlerin düzenli olarak araştırılması yönetim alanında çalışmaların yoğunlaşmasının sebebini açıça ortaya koymaktadır. Önceki çalışmalarda (Tayfun vd., (2016) ve Tekin (2016)) yönetim ve organizasyon ile pazarlama alanlarında yazılan tezlerde ciddi bir rekabet olduğu ancak son yıllarda sürdürülebilirlik ve çevre alanında hazırlanmakta olan tezlerin yönetim ve organizasyon ile pazarlama alanlarına rakip olarak çıkmaya başladığı söylenebilir.

Son yıllarda meydana gelen küresel 1sınmalar, doğal felaketler, insanlarda çevre bilincinin artmasına, doğaya karşı saygı göstermelerine, tatillerini geçirmeyi planladıkları otel, 
destinasyon, ülke vb. yerlerin doğaya karşı tutumlarının ne olduğu turistlerin tatil tercihlerini de etkilemeye başlamıştır. Dolayısıyla da özellikle yerel yönetimler daha fazla turist çekebilmek, insanların arzuladıkları doğal tatil ortamlarını yaratabilmek bu vesileyle de doğal çevreyi korumak için de ciddi yatırımlar yapmaya (yeşil yıldız, mavi bayrak, karbon ayak izi, turuncu bayrak vb.) ve önlemler almaya (geri dönüşüm tesisleri kurma, çevre bilinci oluşturma vb.) özen göstermektedir. $\mathrm{Bu}$ nedenle son yıllarda araştırmaların sürdürülebilirlik ve çevre konuları üzerine yoğunlaşması şaşırtıcı olmamaktadır. Hazırlanmakta olan tezlerde son yıllarda destinasyonlara yönelik çalışmaların da ağırlık kazandığı görülmektedir. Destinasyonlara yönelik çalışmaların sayısının artması hem destinasyonların daha iyi yönetilip pazarlanması hem de alt yapı ve üst yapı arzındaki eksikliklerin giderilmesi açısından yerel yetkililere ve üst mercilere yol gösterici olması açısından önemlidir. $\mathrm{Bu}$ anlamda turistlerin en gözde destinasyonlarının hangileri olduğu, nasıl pazarlanıp yönetildiği bu destinasyonlara ilişkin politika ve planlamalarının düzenli olarak oluşturulup uygulanması gerekliliğinden dolayı tezlerdeki destinasyon ile ilgili konuların artış göstermesini kaçınılmaz kılmaktadır.

Yapılan araştırma ile 18 Haziran 2018'de çıkarılan yönetmelik doğrultusunda Türkiye'de hazırlanma aşamasında olan lisansüstü tezlerin ulusal tez veri tabanına girişlerinde önemli oranda bir artışın gerçekleştiği sonucuna ulaşılmıştır. Bununla birlikte doçent veya doktor öğretim üyesi unvanına sahip öğretim elemanı olarak görevine devam eden birtakım araştırmacılara yönelik lisansüstü tezlerinin YÖK veri tabanında hazırlanıyor kategorisinde sınıflandırılmaya devam ettiği görülmüştür. Ortaya çıkan bu durum YÖK'ün lisansüstü öğrenciler için yayınladığı yönetmeliğin sağlıklı bir şekilde uygulanabilmesinde öğrenciler kadar kurum olarak da YÖK'ün de tez veri tabanı ile ilgili sistemsel çalışmalarını geliştirmesi ve düzenli kontrollerle etkinliğini artırması gerekmektedir.

\section{KAYNAKÇA}

Aksöz, E. O. ve Yücel, E. (2019). Yükseköğretim Kurulu Tez Merkezinde (Yöktez) Engelli Turizmi Alanında Yayımlanmış Lisansüstü Tezlerin Bibliyometrik Analizi, 3. Uluslararası Turizmin Geleceği İnovasyon, Girişimcilik ve Sürdürebilirlik Kongresi, Mersin.

Al, U. (2008). Türkiye'nin Bilimsel Yayın Politikası: Atıf Dizinlerine Dayalı Bibliyometrik Bir Yaklaşım, Yayınlanmamış Doktora Tezi, Hacettepe Üniversitesi, Ankara.

Al, U. ve Soydal, İ. (2012). Dergi Kendine Atıfının Etkisi: Energy Education Science and Technology Örneği, Türk Kütüphaneciliği, 26(4): 699-714.

Alan, A. ve Şen, Ö. (2019). Gastronomi Temalı Festivaller Üzerine Yapılmış Çalışmaların Bibliyometrik Analizi, 20. Ulusal 4.Uluslararası Turizm Kongresi, Eskişehir.

Albayrak, A., Tüzünkan, D. ve Dalkılıç, G. (2019). Kırsal Turizm Ve Türlerine Yönelik Hazırlanan Lisansüstü Tezlerin Bibliyometrik Analizi, 8. Ulusal Kırsal Turizm Kongresi, Bodrum.

Alimanoğlu, Ç. ve Ayazlar, G. (2017). Türkiye'de Kırsal Turizm Konulu Lisansüstü Tez Çalışmaları Üzerine Bibliyometrik Bir İnceleme 2003-2016, 1'st International Rural Tourism and Development Congress, Bursa.

Altaş, A. (2017). Türkçe'ye Tercüme Edilen Gastronomi Kitaplarının Bibliyometrik Analizi. Kırklareli Üniversitesi Sosyal Bilimler Dergisi, 1(1): 103-117.

Altaş, A. ve Acar, Y. (2018). Gastronomi Alanında Yazılan Lisansüstü Tezlerin Bibliyometrik Profili, Aksaray Üniversitesi İktisadi ve İdari Bilimler Fakültesi Dergisi, 10(3): 1-10. 
Altuntop, V. (2019). Kültür Turizmi Çalışmalarının Bibliyometrik Analiz Tekniği İle İncelenmesi, Yayınlanmamış Yüksek Lisans Tezi, Gazi Üniversitesi, Ankara.

Altürk, A. (2018). Türkiye Turizm Literatürünün Durumu Uluslararası Dergi Makalelerinin Bibliyometrik Analizi, Yayınlanmamış Yüksek Lisans Tezi, Batman Üniversitesi, Batman.

Arıca, R. (2014). Seyahat İşletmeciliği Literatürünün Gelişim Süreci Türkiye'de Hazırlanan Lisansüstü Tez Çalışmalarının Bibliyometrik Olarak İncelenmesi, VII. Lisansüstü Turizm Öğrencileri Araştırma Kongresi, Aydın/Kuşadası.

Ayaz, N. ve Türkmen, B. M. (2018). Yöresel Yiyecekleri Konu Alan Lisansüstü Tezlerin Bibliyometrik Analizi, Gastroia: Journal of Gastronomy and Travel Research, 2(2): 22-38.

Aydın, B. (2014). Yükseköğretim Kurulu Tez Merkezinde (Yöktez) Yiyecek İçecek İşletmeciliği Alanında Kayıtlı Bulunan Tezlerin Bibliyometrik Analizi, VII. Lisansüstü Turizm Öğrencileri Araştırma Kongresi, Aydın.

Aydın, B. (2017). Yükseköğretim Kurulu Tez Merkezinde (Yöktez) Yiyecek İçecek İşletmeciliği Alanında Kayıtlı Bulunan Tezlerin Bibliyometrik Analizi, Journal of Multidisciplinary Academic Tourism, 2(1): 23-38.

Aydın, S., Arslan, E. ve Coşkun, İ. O. (2016). Science Direct Veri Tabanında Taranan Dergilerin Bibliyometrik Analizi Turizm Talebi Üzerine Yapılan Çalışmaların İncelenmesi, 17. Ulusal Turizm Kongresi, Muğla.

Aymankuy, Y., Oflaz, M. ve Zamantılı, S. (2018). Yurt Dışında Kış Turizmi İle İlgili Hazırlanmış ve Proquest Veri Tabanında Yer Alan Lisansüstü Tezlerin Bibliyometrik Analizi, Uluslararası Sivas Turizmi Kongresi, Sivas.

Baytok, A., Boyraz, M. ve Kabakulak, A. (2019). Turizm/Turist Rehberliği Bölümü Akademisyenlerinin Profili Türkiye Üniversiteleri Örneği, Uluslararası Sosyal Araştırmalar Dergisi, 12(68): 1038-1049.

Baytok, A., Boyraz, M., Çetin, A., Mutlu, H. ve Katırcioğlu, E. (2018). Ulusal Turizm Kongrelerinde Yer Alan Etik ve Sosyal Sorumluluk Konulu Bildirilerin Bibliyometrisi, 19. Ulusal Turizm Kongresi, Afyonkarahisar.

Baytok, A., Boyraz, M., Çetin, A., Mutlu, H. ve Katırcıoğlu, E. (2019). Etik ve Sosyal Sorumluluk Konulu Bildirilerin Bibliyometrisi Ulusal Turizm Kongreleri Örneği 2009-2017, Güncel Turizm Araştırmaları Dergisi, 3(1): 65-81.

Baytok, A., Boyraz, M. ve Pelit, E. (2019). Turizm İşletmeciliği Alanında Yapılan Yüksek Lisans Tezlerinin Değerlendirilmesi: Afyon Kocatepe Üniversitesi Örneği. Afyon Kocatepe Üniversitesi Sosyal Bilimler Dergisi, 21(1): 287-305.

Boyacıŏlu, E. Z. ve Elmas, Ç. (2019). Turizm ve Festival Olgusunun Bibliyometrik Analizi, Ulusal Turizm Kongresi, Eskişehir.

Boyraz, M. ve Güvenen, Ö. A. (2017). Turizm Alanyazınında Enerji Su ve Atık Yönetimi İle İlgili Çalışmaların Bibliyometrik Analizi 2006-2016, Uluslararası Batı Asya Turizm Araştırmaları Kongresi, Van.

Bozok, D., Kılıç, S. N. ve Özdemir, S. S. (2017). Turizm Literatüründe Kırsal Turizmin Bibliyometrik Analizi, Interational Journal of Human Sciences, 14(1): 187-202.

Büyükşalvarcı, A. ve Keleş, H. (2019). Turizm Alanında Yazılan Lisansüstü Tezlerin Bibliyometrik Açıdan İncelenmesi, Journal of Tourism And Gastronomy Studies, 7(4): 2758-2773. 
Canik, S. ve Güneren, E. (2019). Sağlık Turizmini Konu Alan Lisansüstü Tezlerin Bibliyometrik Değerlendirmesi 1988-2017, Anatolia: Turizm Araştırmaları Dergisi, 30(2): 125-134.

Ceylan, V. ve Sarışık, M. (2018). Moleküler Gastronomi Alanında Yapılan Çalışmaların Bibliyometrik Analizi Üzerine Bir Araştırma, I. Uluslararası Turizmde Yeni Jenerasyonlar ve Yeni Trendler Kongresi, Sakarya.

Civelek, M. ve Türkay, O. (2017). Turizmi Konu Alan Lisansüstü Çalışmalarının Bibliyometrik Profili, Uluslararası Batı Asya Turizm Araştırmaları Kongresi, Van.

Çakıcı, A., Yıldırım, O. ve Karacaoğlu, S. (2013). Ulusal Turizm Kongreleri Bildirilerinin Bibliyometrik Profili, 14. Ulusal Turizm Kongresi, Kayseri.

Çalhan, H. ve Çakıcı, A. (2019). Uluslararası İndekslerce Taranan Kış Turizmi Başlıklı Makalelerin Bibliyometrik Analizi, 1. Uluslararası Kış Turizmi Kongresi, Erzurum.

Çelik, S. (2019). Turizm Alanında Liderlik Konusu ile İlgili Hazırlanmış Tezlere Yönelik Bibliyometrik Bir Analiz, International Congress on Economic and Administrative Sciences, Şırnak.

Çelik, S. (2019). Turizm Alanında Liderlik Konusu İle İlgili Hazırlanmış Tezlere Yönelik Bibliyometrik Bir Analiz. International Journal of Academic Value Studies, 5(4): 516-527.

Çıkrık, R. (2018). Türkiye'de Turizmin Etkileri Konusunda Yerel Halkın Bakış Açısını Ortaya Koyan Lisansüstü Tezlerin Bibliyometrik Analizi, Yayınlanmamış Yüksek Lisans Tezi, Nevşehir Hacı Bektaş Veli Üniversitesi, Nevşehir.

Çolakoğlu, Ü., Altun, H. E. ve Kıykaç, B. (2018). Türkiye' de Medikal Turizm Konulu Lisansüstü Tez Çalışmalarının Bibliyometrik Profili 2008-2018, Prof. Dr. Hasan Olalı Turizm Sempozyumu, İzmir.

Çolakoğlu, Ü., Altun, H. E. ve Kıykaç, B. (2019). Türkiye'deki Medikal Turizm Tezlerinin Bibliyometrik Profili 2008-2018, Anatolia: Turizm Araştırmaları Dergisi, 30(2): 135-143.

Demiral, N. Ö. ve Saatçi, G. (2019). Kültürel Miras Konulu Lisansüstü Tezlerin Bibliyometrik Analizi, Avrasya Bilimler Akademisi Avrasya Eğitim ve Literatür Dergisi, 7-19.

Demirbulat, Ö. ve Tetik Dinç, N. (2017). Sürdürülebilir Turizm Konulu Lisansüstü Tezlerin Bibliyometrik Profili, Seyahat ve Otel İşletmeciliği Dergisi, 14(2): 20-30.

Dursun, M. T., Bayraktaroğlu, E. ve Kozak, N. (2018). 2003 - 2018 Yılları Arasında Turizm Alanında Detay Yayıncılık Tarafından Yayımlanan Kitapların Bibliyometrik Analizi, Prof. Dr. Hasan Olalı Turizm Sempozyumu, İzmir.

Erkol Bayram, G., Bayram, A. T. ve Karaçar, E. (2017). Sürdürülebilir Turizm Bibliyometrik Analiz, $1^{\text {st }}$ International Sustainable Tourism Congress, Kastamonu.

Evren, S. ve Kozak, N. (2012). Türkiye'de 2000-2010 Yılları Arasında Yayımlanan Turizm Konulu Makalelerin Bibliyotektik Analizi, VI. Lisansüstü Turizm Öğrencileri Araştırma Kongresi, Antalya.

Güçlü Nergiz, H. (2014). Türkiye'de Lisansüstü Turizm Tezlerinin Bibliyometrik Profili 19902013,VII. Lisansüstü Turizm Öğrencileri Kongresi, Aydın.

Güçlü Nergiz, H. ve Kapucuoğlu, M. İ. (2018). Dergipark'a Kayıtlı Turizm İşletmeciliği Dergilerinde Yayımlanan Gastronomi ve Yiyecek İçecek İşletmeciliği Konulu Makalelerin Bibliyometrik Analizi. $7^{\text {th }}$ International Conference on Business Administration, Çanakkale.

Gül, M. ve Gül, K. (2018). Kırsal Kalkınma ve Kırsal Turizm Konulu Lisansüstü Tezlerin Bibliyometrik Profili, International Journal of Social And Economic Sciences, 8(2): 56-62. 
Gül, M. ve Gül, K. (2018). Turizmde İnovasyon Konulu Lisansüstü Tezlerin ve Makalelerin Bibliyometrik Analizi, 3. Uluslararası Doğu Akdeniz Turizm Sempozyumu, İskenderun.

Güneren, E. ve Canik, S. (2018). Sağllk Turizmini Konu Alan Lisansüstü Tezlerin Bibliyometrik Değerlendirmesi 1988-2017, Prof. Dr. Hasan Olalı Sempozyumu, İzmir.

Güzeller, C.O. ve Çeliker, N. (2017). Geçmişten Günümüze Gastronomi Bilimi Bibliyometrik Bir Analiz, Journal of Tourism and Gastronomy Studies, 5(2): 88-102

Güzeller, C. O. ve Çeliker, N. (2018). Bibliometric Analysis of Tourism Research for the Period 2007-2016, Advances in Hospitality and Tourism Research, 6(1): 1-22.

İpkoparan, B. ve Akbaba, A. (2019). Turizm Alanında Kano Modeli Kullanılarak Yapılmış Akademik Çalışmaların Bibliyometrik Analizi, 5. Uluslararası Sosyal Bilimler Sempozyumu, Antalya.

Jafari, J. and Ritchie, J. R. B. (1981). Towards a Framework for Tourism Education. Annals of Tourism Education, 8: 13-33.

Karabacak, S. E. ve Güçlü Nergiz, H. (2019). Türkiye'de Turizm Anabilim Dalında Örgütsel Davranış Konulu Lisansüstü Tezlere Yönelik Bir Bibliyometrik İnceleme, Uluslararası Marmara Fen ve Sosyal Bilimler Kongresi, Kocaeli.

Karagöz, D. ve Yüncü, H. R. (2013). Sosyal A ̆ Analizi ile Turizm Alanında Yazılmış Doktora Tezlerinin Araştırma Konularının İncelenmesi. Adryaman Üniversitesi Sosyal Bilimler Enstitüsü Dergisi, 6(15): 205-232.

Kaygalak Çelebi, S. ve Kırlar, B. (2019). Turizm Rehberliği Alanında Yapılan Makalelerin Bibliyometrik Analizi, II. Ulusal Turizm Rehberliği Kongresi, Aydın.

Kılıç, A., Oflaz, M., Mısır, İ. ve Hacıoğlu, N. (2018). Kırsal Turizm Alanında Hazırlanmış Ulusal ve Uluslararası Lisansüstü Tezlerin Bibliyometrik Analizi, ${ }^{\text {nd }}$ International Rural Tourism and Development Congress.

Kozak, N. (1995). Türkiye Turizm Tezleri Bibliyografyası 1952-1995. Ankara: Anatolia Yayıncllı.

Köroğlu, A., Özkan, E. ve Curkan, S. C. (2017). Türkiye' de Turizmde Sosyal Medyanın Kullanımı Konulu Yayınların Bibliyometrik Profili, 1. Uluslararası Demirci Sempozyumu, Manisa.

Kurtgözlü, M. ve Güçlü Nergiz, H. (2019). Türkiye'de Turizm Alanındaki Doktora Tezlerinin Bibliyometrik Profili 2014-2018, Uluslararası Marmara Fen ve Sosyal Bilimler Kongresi, Kocaeli.

Lisansüstü Eğitim ve Öğretim Yönetmeliği (2016). Resmi Gazete Tarihi: 20.04.2016, Resmi Gazete No:29690, https://www.yok.gov.tr/kurumsal/mevzuat (Erişim Tarihi: 20.01.2020)

Nebioğlu, O. ve Kalıpçı, M. B. (2019). Planlı Davranış Teorisi ve Turizm Üzerine Yapılan Uluslararası Yayınların Bibliyometrik Analizi, 6. Uluslararası Sosyal, Beşeri ve İdari Bilimler Sempozyumu, Antalya.

Nebioğlu, O. ve Kalıpçı, M. B. (2020). Planlı Davranış Teorisi ve Turizm Üzerine Yapılan Uluslararası Yayınların Bibliyometrik Analizi. Türk Turizm Araştırmaları Dergisi, 4(1): 1-14.

Güçlü Nergiz, H. (2014). Türkiye'de Lisansüstü Turizm Tezlerinin Bibliyometrik Profili (19902013). VII. Lisansüstü Turizm Öğrencileri Araştırma Kongresi, Aydın/Kuşadası.

Olcay, A., Karaçil, G. ve Sürme, M. (2017). Helal Turizm Alanının Bibliyometrik Profili, I. Uluslararası Helal Turizm Kongresi, Alanya. 
Olcay, A., Karaçil, G., ve Sürme, M. (2018). Helal Turizm Alanının Bibliyometrik Profili, Iğdır Üniversitesi Sosyal Bilimler Dergisi, 2(15): 389-408.

Özel, Ç.H. ve Kozak, N. (2012). Turizm Pazarlaması Alanındaki Makalelerin Bibliyometrik Profili 2000-2011, VI. Lisansüstü Turizm Öğrencileri Araştırma Kongresi, Antalya.

Özsoy, A. ve Çokal, Z. (2018). Türkiye'de Turist Rehberliği Alanında Yayımlanmış Lisansüstü Tezlerin Bibliyometrik Analizi 1989-2018, $2^{\text {nd }}$ International EMI Entrepreneurship Social Sciences Congress, Nevşehir.

Pritchard, A. (1969). Statistical Bibliography or Bibliometrics? Journal of Documentation, 25(4): 348349.

Sandıkc1, M. ve Mutlu, H. (2019). Gastronomi Alanında Yayınlanan Makalelerin Bibliyometrik Profili 2013-2017, Sosyal Bilimler Dergisi, (33): 32-42.

Sandıkcı, M., Boyraz, M., Mutlu, H. ve Gökçe, F. (2018). Gastronomi Araştırmaları Bibliyografyası Bildiri Makale Tez 2013-2017, Ankara: Detay Yayıncillk.

Sünnetçioğlu, A. Yalçınkaya, P., Olcay, M. ve Mercan, Ş. O. (2017). Turizm Alanında Yazılmış Olan Gastronomiye İlişkin Tezlerin Bibliyometrik Profili, Journal of Tourism and Gastronomy Studies, 5(2): 345-354.

Şahin, E., Akdağ, G., Çakıcı A. ve Onur, N. (2018). Gastronomi ve Mutfak Sanatları Anabilim Dallarında Yayınlanan Tezlerin Bibliyometrik Analizi, Güncel Turizm Araştırmaları Dergisi, 30-41.

Şahin, E., Akdağ, G., Çakıcı, C. ve Onur, N. (2018). Gastronomi ve Mutfak Sanatları Anabilim Dallarında Yayınlanan Tezlerin Bibliyometrik Analizi, Gastronomi Zirvesi, Ankara.

Şahin, S. ve Acun, A. (2015). Turist Rehberliği Alanının Bibliyometrik Profili Makaleler ve Lisansüstü Tezler, 16. Ulusal Turizm Kongresi, Çanakkale.

Şalvarcı, S. ve Aylan, F. K. (2019). Analysis of Phd Dissertations in Tourism (2014-2018). Journal of Gastronomy, Hospitality and Travel (JOGHAT), 2(1): 29-37.

Tayfun, A., Küçükergin, F. N., Aysen, E., Eren, A. ve Özekici, Y. K. (2016). Turizm Alanında Yazılan Lisansüstü Tezlere Yönelik Bibliyometrik Bir Analiz, Gazi Üniversitesi Turizm Fakültesi Dergisi, 1(1): 50-69.

Tekin, Ö. A. (2016). Türkiye'deki Lisansüstü Turizm Tezlerinde Odaklanılan Konular: 1984-2015. Uluslararası Alanya İşletme Fakültesi Dergisi, 8(2): 175-187.

Temizkan, S. P., Çiçek, D. ve Özdemir, C. (2015). Sağllk Turizmi Konusunda Yayınlanan Makalelerin Bibliyometrik Profili, International Journal of Human Sciences, 12(2): 394-415.

Toksöz, D. ve Birdir, K. (2016). Turizm Alan Yazında Kültürel Mirasla İlgili Çalışmaların Bibliyometrik Profili 2006-2015, 1't International East Mediterranean Tourism Symposium, Magusa.

Tonbul, Y. (2017). Sosyal Bilimler Enstitülerinin Lisansüstü Eğitimin Niteliğini Artırmadaki Rolü, Yüksekögretim ve Bilim Dergisi, 7(1): 150-162.

Türktarhan, G. (2014). Türkiye'de Turizm Alanyazınının İncelenmesi Sistematik Türkiye Turizm İşletmeciliği Bibliyografyası 1929-1984 Üzerine Bir İnceleme, VII. Lisansüstü Turizm Öğrencileri Araştırma Kongresi, Aydın.

Türktarhan, G. (2014). Türkiye'de Turizm Pazarlaması Alanyazınının Gelişim Süreci 1990-2012, VII. Lisansüstü Turizm Öğrencileri Araştırma Kongresi, Aydın. 
Türktarhan, G. ve Kozak, N. (2012). Turizm Yıllığı'nın Bibliyometrik Profili, VI. Lisansüstü Turizm Öğrencileri Araştırma Kongresi, Antalya.

Yağcı, P., Ulusoy Yıldırım, H., Avcıkurt, C. ve Köroğlu, Ö. (2018). Kış Turizmi Konulu Makalelerin Bibliyometrik Analizi, Uluslararası Sivas Turizmi Kongresi, Sivas.

Yalın, G., İlsay, S. ve Avcıkurt, C. (2014). Turizm Alan Yazınında Engelliler İle İlgili Çalışmaların Bibliyometrik Profili, 15. Ulusal Turizm Kongresi, Ankara.

Yeşilyurt, H. ve Koçak, N. (2018). Yerel Halkın Turizm Gelişimine Yönelik Desteğini İnceleyen Makalelerin Bibliyometrik İncelenmesi. Uluslararası Batı Asya Turizm Araştırmaları Kongresi, Van.

Yılmaz, İ. ve Toprak, L. S. (2017). Türkiye'de Turizm Alanındaki Bibliyometrik Yayınların Profili, Uluslararası Batı Asya Turizm Araştırmaları Kongresi, Van.

YÖKBYS (Yükseköğretim Bilgi Yönetim Sistemi) (2020). Birim İstatistikleri, Türlerine Göre Birimler. https://istatistik.yok.gov.tr/ Erişim Tarihi (06.02.2020).

YÖKB (Yükseköğretim Kurulu Başkanlığı) (2020). Ulusal Tez Merkezi, https://tez.yok.gov.tr/UlusalTezMerkezi/giris.jsp Erişim Tarihi (10.01.2020).

YÖKM (Yükseköğretim Kurulu Mevzuat) (2020). https://tez.yok.gov.tr/Ulusal Tez Merkezi/tezTeslimKılavuz.jsp Erişim Tarihi (10.01.2020).

Yükseköğretim Kanunu (2019) https://www.yok.gov.tr/ kurumsal/mevzuat (Erişim Tarihi: 10.01.2020).

Zan, U. B. (2012). Türkiye'de Bilim Dallarında Karşılaştırmalı Bibliyometrik Analiz Çalışması, Yayınlanmamış Doktora Tezi, Ankara Üniversitesi, Ankara 